\author{
Asian Development Policy Review \\ $\operatorname{ISSN}(e):$ 2313-8343 \\ $\operatorname{ISSN}(p): 2518-2544$ \\ DOI: 10.18488/journal.107.2020.84.298.318 \\ Vol. 8, No. 4, 298-318. \\ (C) 2020 AESS Publications. All Rights Reserved. \\ URL: www.aessweb.com \\ check for
updates
}

\title{
SPILLOVER OF FINANCIAL INNOVATIONS DURING COVID-19: A CROSS-COUNTRY ANALYSIS
}

\author{
Sanjay Kumar \\ Rout
}

\author{
Centre for Development Studies, Prasanth Nagar, Ulloor, \\ Thiruvananthapuram, Kerala, India. \\ Email:sanjayrout1992@gmail.com Tel:+918848338987
}

(A) Check for updates

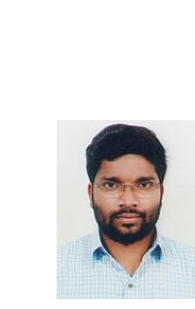

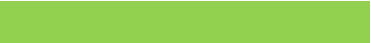

Article History

Received: 10 September 2020 Revised: 22 September 2020 Accepted: 28 September 2020 Published: 2 October 2020

\section{Keywords}

Covid-19 pandemic

Financial markets

Financial shocks spillover

Government bond yield price

Diebold

Yilmaz spillover approach.

JEL Classification: C32; C58; G01; G15; I19.

\begin{abstract}
The main objective of this work is to investigate the magnitude of cross-country financial innovations spillover and its direction among top ten economies (in terms of gross domestic product) such as US, China, Japan, Germany, India, UK, France, Brazil, Canada, and Russia, during Covid-19 pandemic (from 1st January to 10th July 2020). Employing Diebold and Yilmaz's VAR based spillover approach; the empirical results demonstrate that the financial innovations spillover is very high during Covid-19 pandemic. Specifically, the total financial sector innovations spillover for full sample is $49.20 \%$, on average, when estimation based on only 3 -months government bond yield price whereas total spillover is $62 \%$ on average when spillover is measured through composite financial sector index. The marginal variation in empirical results between two models due to the following reasons; (i) latter model is based on composite indices that capture a wider picture of cross-country spillover, and (ii) spillover is higher with long terms bond yield which incorporated in latter model. The empirical results imply more than one-half of the total variance of forecast errors is explained by innovations spillover across countries. Nevertheless, it will provide better guidance to investors, portfolio managers, and policymakers during this current economic disaster to make right decision. The result is found to be robust.
\end{abstract}

Contribution/ Originality: This study is one of very few studies that have investigated and provide a quantitative estimation of financial innovations spillover across top ten economies during covid-19 pandemic.

\section{INTRODUCTION}

The impact of Coronavirus (Covid-19) pandemic is ubiquitous since its inception in December 2019 in Wuhan (China) and has infected over 13 million people and death over half a million people globally in six months. Specifically, the total infected number of individuals and the number of deaths globally has outreached to $13,459,235$ and 518221 respectively (as on $15^{\text {th }}$ July 2020, data source from Worldometer ${ }^{1}$ ). The US $(3,545,077)$ is mostly affected, followed by Brazil (1,931,204), India (937,487), Russia (739,947), Peru (333,867), and so on in terms of the total infected individuals (further detail about covid-19 figure, see Figure A2 and A3 in Appendix 2). Both total infected individuals and total deaths are moving upward globally although receding in some regions.

${ }^{1}$ htt://www.worldometer.info/coronavirus/\#countries 
Nevertheless, in a strongly integrated world, the real impact of Covid-19 pandemic beyond the virus infections, death of individuals, and a particular region.

The Covid-19 remodel the global economic outlook affecting economic activities gravely. It is because of the following reasons such as (i) international transmission of Covid-19 virus (transmitted to more than 200 countries), (ii) preventive measure to control the transmission (i.e. social distancing policy, lockdown, and shutdown, closing the international border, stay at home policy, etc.) and (iii) policy responses (both fiscal and monetary responses to revive economic activities in each country). The preventive actions undertaken by every individual economy have had an instantaneous impact on economic activities intensely. To stimulate economic activities, the Government of respective country undertook both fiscal and monetary measures. The actions and reactions restructured the global economic outlook.

However, the financial market is more sensitive to Covid-19 than any other market. Even a mild disruption in the smooth function of economy divulges in the financial market instantaneously. For instance, the Global stock market lost \$6 trillion (value) over six days from 23 to 28 February (S\&P Dow Jones Indices), the S\&P 500 index fell by $28 \%$ between February. 20 and March. 19, the FTSE 250 index fell by 41.3\%, Nikkei fell by $29 \%$, Citigroup’s share price fell by 49\%, JP Morgan Chase’s share fell by 38\%, Barclays' share price fell by 52\% (Ozili \& Arun, 2020), even when Covid-19 was an epidemic. According to McKibbin and Fernando (2020) and Akhtaruzzaman, Boubaker, and Sensoy $(2020)^{2}$, the global financial market has been sensitive to Covid-19 pandemic. Further, the downward adjustments of projected economic activity and increased risk aversion have led to a major repricing and repositioning in global financial markets (Board, 2020).

Following such a tremendous global cataclysm, the literature on economic impact of Covid-19 pandemic has been growing rapidly and the large bodies of research papers so far have been circulated are two kinds. Firstly, some of the studies examine epidemiological, demographic, clinical issues of pandemic, and its outbreak. Secondly, some analyses are based on comprehensive and indicative synopsis on the perceived and possible impact on economic activity including the financial matter that may emerge tomorrow. For example, Barua (2020), Goodell (2020), Board (2020), Abdul and Mia (2020), Abiad, Arao, and Dagli (2020), Gurría (2020), Ozili and Arun (2020) and many international organizations such as UNDP, UNCTAD, World Bank, IMF, ILO, OECD, and ADB, are attempted to visualize current and future economic implication of Covid-19 pandemic comprehensively based on observation.

The limited number of papers produces a quantitative estimation of Covid-19 impact on economic activities including financial markets. Such studies include; Baker et al. (2020) examines the impact of Covid-19 on the US stock market relative to the previous infectious disease outbreak, Corbet, Larkin, and Lucey (2020) investigated the contagion effect of Covid-19 between stock markets in China, Ali, Alam, and Rizvi (2020) analyzed financial markets downfall and volatility, Corbet, Hou, Hu, Lucey, and Oxley (2020) examines the impact on companies whose identity is similar with Covid-19 virus, Shehzad, Xiaoxing, and Kazouz (2020) compared the impact of Covid19 and the global financial crisis on returns and variance of stock markets, Albulescu (2020) impact of the official announcement of daily new Covid-19 infected cases and death on financial market volatility index, Akhtaruzzaman et al. (2020) how financial contagion happens viz financial and non-financial firms between China and G7 economies, McKibbin and Fernando (2020) quantify the potential global economic cost of Covid-19 underlying various possible scenarios, Maliszewska, Mattoo, and Van Der Mensbrugghe (2020) illustrate the transmission channels and heterogeneous impact of pandemic on output and trade.

However, to the best of my attentiveness, none of these literature has attempted to investigate the magnitude and direction of financial innovations spillover during Covid-19 pandemic, apart from Akhtaruzzaman et al. (2020). Importantly, Akhtaruzzaman et al. (2020) have considered a very limited period (December $31^{\text {st }}$, 2019 to March

\footnotetext{
${ }^{2}$ See also Akhtaruzzaman et al. (2020). Financial contagion during COVID-19 crisis.
} 
2020) of Cvid-19 which may not unleash the actual magnitude of direction of spillover. Therefore, to understand financial market responses and its agents comprehensively, this paper aims to assess the magnitude of cross-country financial spillover and its direction during Covid-19 pandemic (from $1^{\text {st }}$ January to $10^{\text {th }}$ July 2020).

This paper aims to analyze the magnitude and direction of financial shocks spillover among top ten economies such as the US, China, Japan, Germany, India, UK, France, Brazil, Canada, and Russia during Covid-19 period. The study has chosen these ten largest economies in the sample for the following reasons; (i) altogether they covered more than $65 \%$ of world gross domestic product (GDP), (ii) higher share of world GDP likely to affect severely compared to other economies, (iii) they are also having a substantial share of Covid-19 infected individuals which reached approximately $65 \%$ of total infected individuals globally. Therefore, these sample units are supposed to be appropriate to investigate financial innovations spillover globally.

Following Diebold and Yilmaz (2012) spillover measures, this study evaluates the magnitude and direction of financial shocks spillover during Covid-19 pandemic. This method has gained a wide range of popularity in its application particularly in analyzing financial assets markets or financial markets connectivity empirically. For instance, Diebold and Yilmaz (2012) analyzed financial assets markets interaction across the US. Similarly, Klößner and Wagner (2014) spillover between markets, Kumar (2013) returns and volatility spillover, Cronin (2014) examines the relationship between money and financial assets markets in the US, Klößner and Sekkel (2014) financial spillover for six developed countries, Antonakakis and Vergos (2013) examines the interlinkage of government bond yield spread, Chevallier and Ielpo (2013) examine volatility in commodity markets, etc.

However, apart from Akhtaruzzaman et al. (2020) none of the papers have used this method to analyze financial shocks spillover during Covid-19. The Diebold and Yilmaz (DY) method provide several interesting regularities such as (i) it can assess spillover in assets portfolio, asset markets, etc. both within and across countries Diebold and Yilmaz (2012) (ii) it is insensitive to order, hence, provides decisive results, (iii) it quantifies directional spillover, total spillover, net spillover, and pairwise spillover, (iv), it summaries the spillover in a single number, so, it is easy to interpret. According to Urbina $(2013)^{3}$ this method provides an assessment of spillover that not only stemming from an unstable period but also a stable period. Hence, DY method is a matter of interest for this analysis.

To capture financial shock spillover, I used several bond yields prices as a proxy to represent the financial market. The study used Government bond yield price for the following reasons; First, the existing literature have used stock market indices for analysis during Covid-19 and none of the studies investigated the financial innovations spillover using bond yield price. Secondly, a rising and falling bond yield price also significantly indicates economic boom or economic slowdown, hence can represent the financial market well. Thirdly, global investor sentiment can be regulated through bond yield price. Thus, considering bond yield price and its important features for analysis of financial innovations spillover during Covid-19 globally contribute to literature significantly.

This empirical analysis has a substantial number of economic policy implications from the view of current economic outlooks. First, the current outbreak of Covid-19 virus has been and continues to be very unpredictable globally. Secondly, the economic impact of Covid-19 is tremendously uncertain that makes it an uphill task for policymakers to formulate precise macroeconomic policies, Thirdly, during Covid-19 pandemic, macroeconomic fundamentals are naturally weak to function smoothly and trigger a sudden loss of investor confidence. Fourthly, the market participants may consider this financial market relationship among different countries to predict the future impact of pandemic effectively. Fifthly, it may help policymakers to understand the financial market structure of top ten economies in a better way and then design their policies, and so on. Therefore, it may provide better guidance to investors, portfolio managers, and policymakers during this current economic disaster to make right

${ }^{3}$ See, Urbina (2013) investigation based on "Financial Spillovers Across Countries: Measuring shock transmissions". 
decision for their business. Employing Diebold and Yilmaz (2012) VAR based spillover approach, the empirical results demonstrate that magnitude of financial innovations spillover is very high among the US, China, Japan, Germany, India, UK, France, Brazil, Canada, and Russia, during Covid-19 pandemic (from 1st January to 10th July 2020).

The rest of the manuscript is organized as follows. Section 2 presents the visualization of data. Section 3 provides descriptive statistics. Section 4 provides data descriptions. Section 5 discusses the formation of composite financial sector index. Section 6 provides correlation analysis. Section 7 discusses methodology. Section $8^{5}$ extends discussion of empirical results. Section 9 contains results for robustness checks. Section 10 concludes.

\section{VISUALIZATION OF DATA}

US
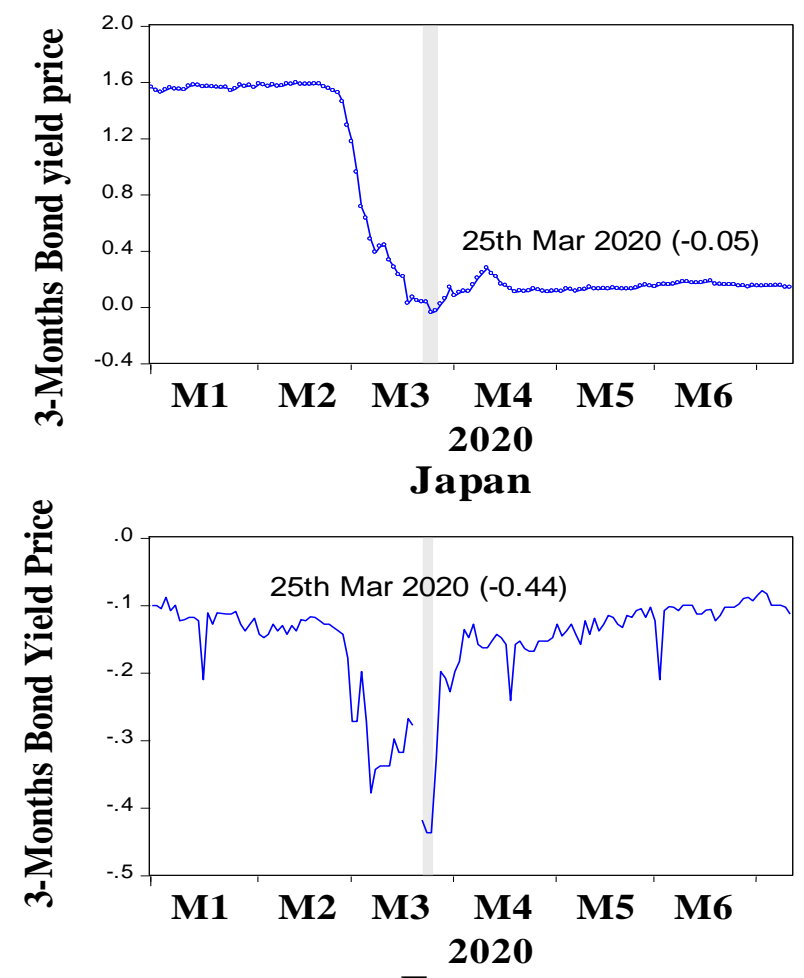

France

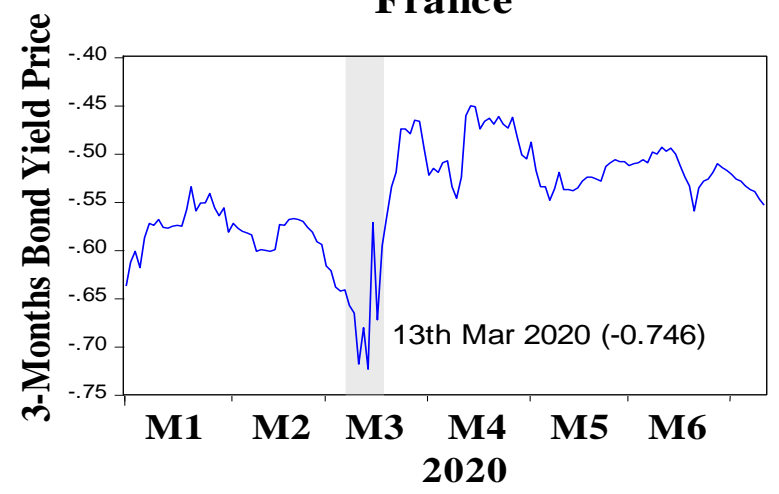

UK
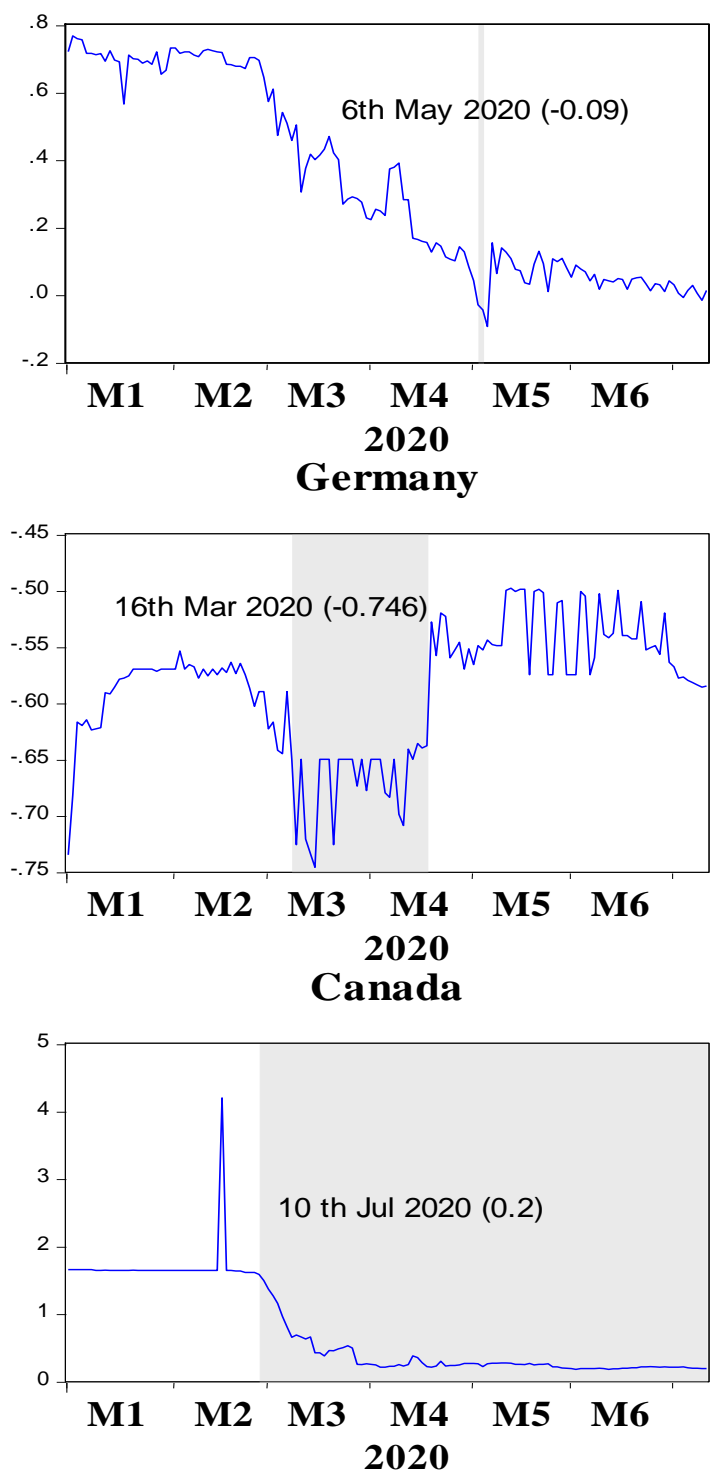

${ }^{4}$ See Diebold and Yilmaz (2012). Better to give than to receive: Predictive directional measurement of volatility spillovers.

${ }_{5}^{5}$ The shortcoming of this analysis is that this study does not analyse the rolling sample analysis under Diebold and Yilmaz spillover approach, because the study is based on data constrained, that is, the study used only limited number of observation (from $1^{\text {st }}$ January 2020 to $10^{\text {th }}$ July 2020 , daily data). To undertake rolling sample analysis required the large number of observations. 


\section{China}
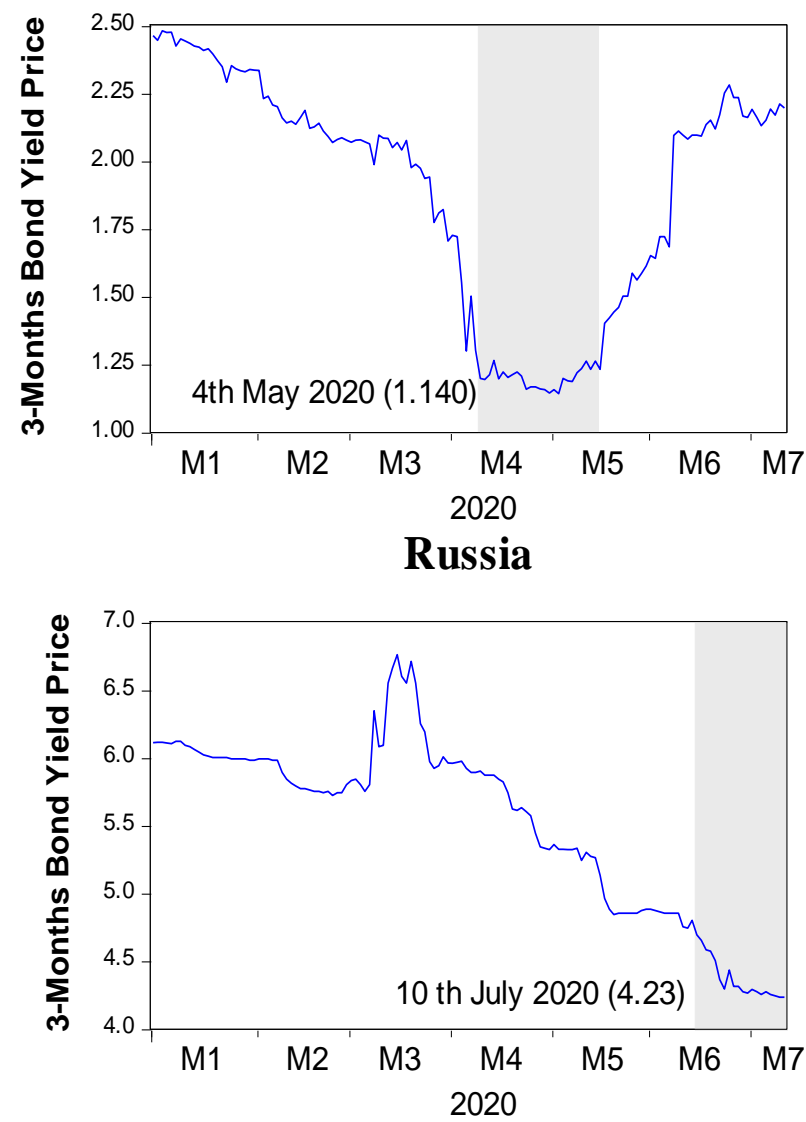

India

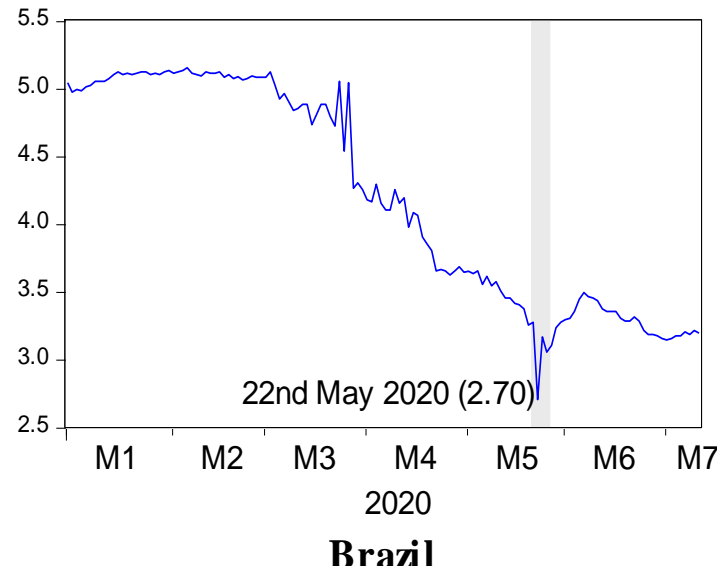

Brazil

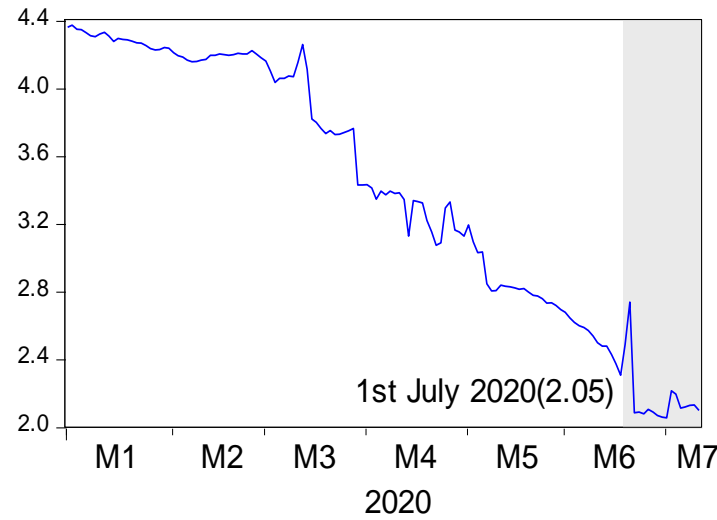

Figure-1. Patterns of 3-months government bond yield price (BYP) during Covid-19.

Source: Author's own estimation based on data obtained from Investing.com ${ }^{6}$.

Note: Figure 1 shows the trend of 3- months government bond yield price of the US, UK, Japan, Germany, France, Canada, India Russia, and Brazil during Covid-19 pandemic ( $1^{\text {st }}$ January to $10^{\text {th }}$ July 2020). For China, the study has taken a 1-year bond yield price due to unavailability of 3 -months bond yield price. The shaded area indicates a period of minimum bond yield price during Covid-19.

Figure 1 shows how Covid-19 outbreak that encouraged social distancing, increasing number of lockdowns and shutdowns, monetary and fiscal stimulant packages, national and international travel restriction rigorously affected the financial markets and particularly bond yield prices of major economies like the US, UK, Japan, Germany, France, Canada, China, India, Russia and Brazil for the period $1^{\text {st }}$ January 2020 to $10^{\text {th }}$ July 2020. Importantly, the trend of bond yield price can be divided into two kinds of patterns among countries; (i) rapid downward fall and then upward trend in Japan, Germany, France, and China and (ii) continuous downward trend in the US, UK, Canada, India, Russia, and Brazil. It implies two things; first, the financial market of Japan, Germany, France, and China are revitalized and stabilized, second, as a result of first, now international investors can diversify their capital investment to the stabilized financial markets.

Specifically, the financial market of the US, UK, and Canada economies were stable throughout January and up to early last week of February. A few cases were reported when these stock markets collapsed drastically in the last week of February. This fall is strongly related to the large number of infected individuals reported in China in February. Because China is globally connected, anything that happens in China affects the global economy. Since the last week of February, there is an exponential fall in bond price and reached a minimum thereafter, the bond price stabilized at its minimum and the daily new infected individuals (See Figure A3 in Appendix 2) at its maximum in the US but minimum in UK and Canada.

In contrast, the number of newly infected individuals is falling drastically after reaching its maximum in March-April in Japan, Germany, and France and maximum in February in China, therefore, their financial market

${ }^{6}$ https://www.investing.com/rates-bonds/world-government-bonds 
has been stabilizing in June and July 2020. There is an inverse relationship between the number of infected individuals and the performance of financial markets. However, it shows from Figure 1, the globalization of Covid19 outbreak and its negative economic impacts have generated havoc across all countries in the world.

In terms of individual financial markets (Figure 2(a)), bond yield price (BYP) of China and Germany have recorded the highest intraday variation compared to other markets (countries) for the period $1^{\text {st }}$ January 2020 to $10^{\text {th }}$ July 2020. The higher degree of intraday variation remains longer period in Germany, followed by China, France, Canada, and the US. For other countries, a higher level of variation remains for a short period. Interestingly, between $1^{\text {st }}$ January 2020 and $10^{\text {th }}$ July 2020 (Covid-19 period), the degree of intraday variation is very high between $27^{\text {th }}$ February and $1^{\text {st }}$ April 2020 in all most all the markets as shown by the shaded area in Figure 2 (b).
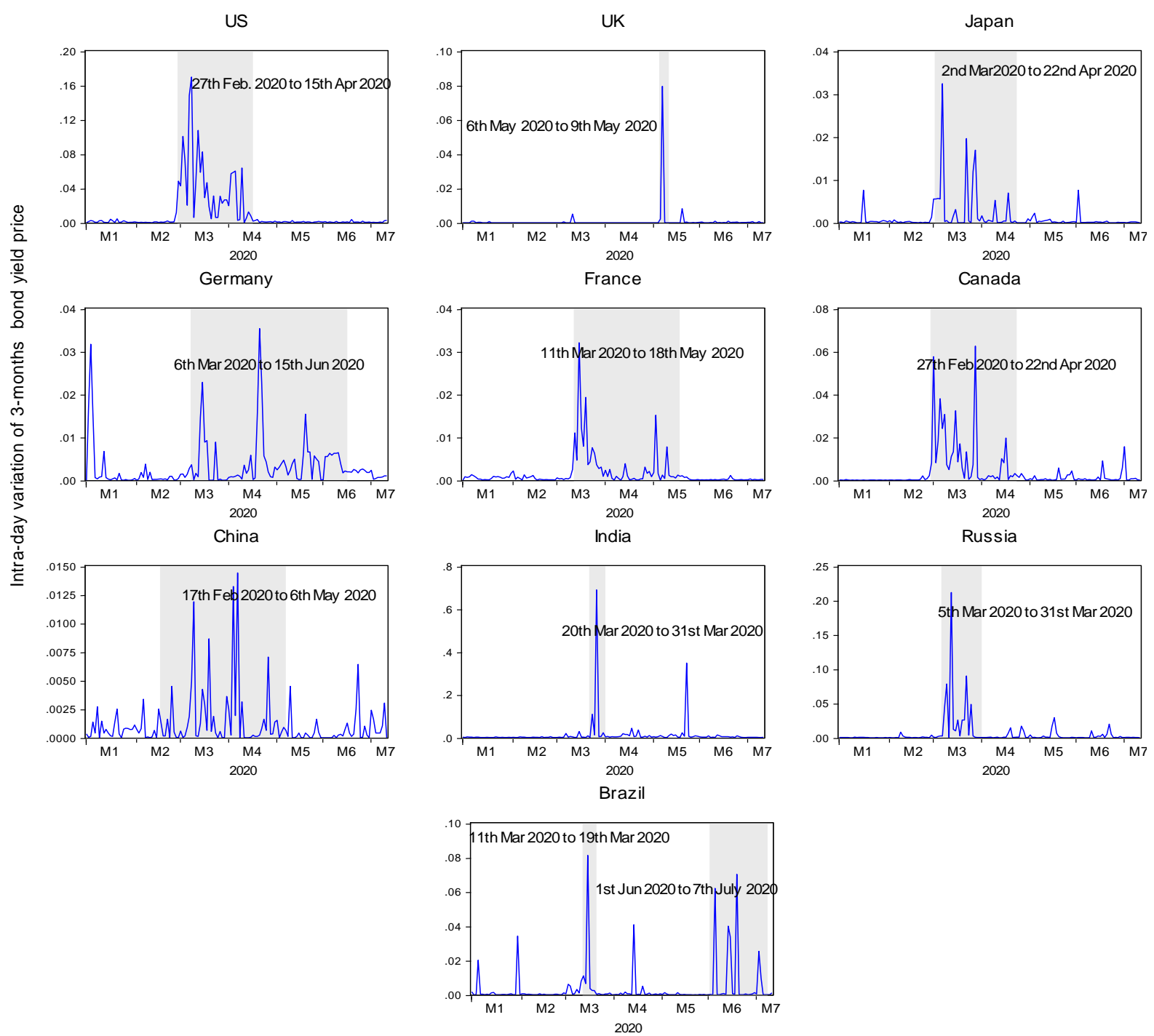

Figure-2(a). Country-wise intra-day variation in 3-months bond yield price. Source: Author's own estimation based on data obtained from Investing.com 


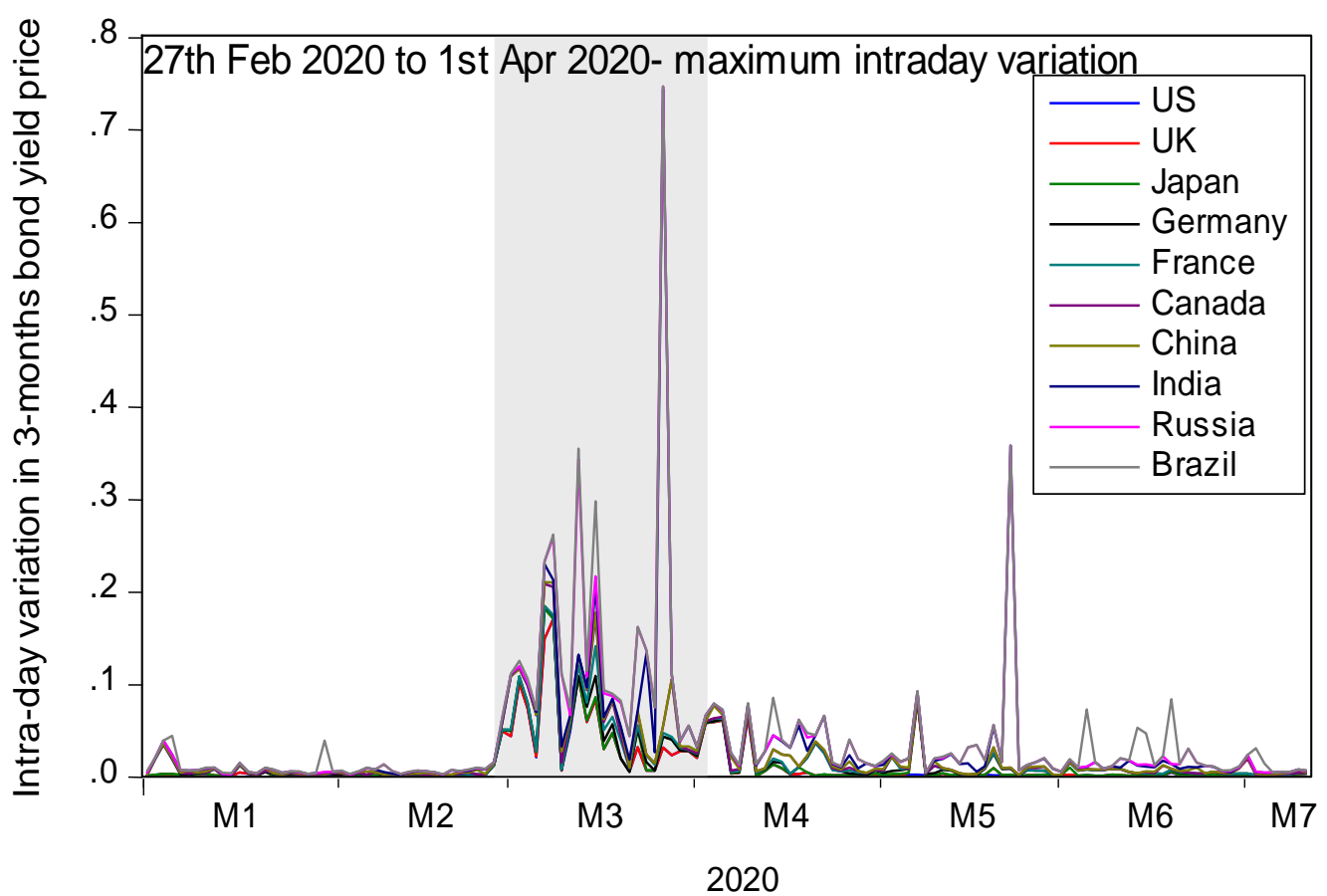

Figure-2(b). Intraday variation in 3-months bond yield price (BYP) of all countries. Source: Author's estimation based on data obtained from Investing.com ${ }^{7}$.

Note: Figure 2(a) demonstrate the country-wise intraday 3-months bond yield price variation. It simply calculated as follows, intraday variation in bond yield price $=(\text { maximum value-minimum value })^{2}$. Figure $2(\mathrm{~b})$ is just plotted the intraday bond yield price all together (all countries) for more clarity or to find the period of higher variation in bond yield price. The shaded area indicates a higher level of variation in bond yield price and period also mentioned inside figure.

\section{DESCRIPTIVE STATISTICS}

Table 1 presents the descriptive statistics of a 3-months government bond yield price for the US, UK, Japan, Germany, France, Canada, China, India, Russia, and Brazil between $1^{\text {st }}$ January 2020 and $10^{\text {th }}$ July 2020. On average, the bond yield price in Russia (5.508), India (4.205), and Brazil (3.399) is much higher compared to others such as China (1.890), Canada (0.746), and then followed by the US, UK, Japan, France, and Germany. Unlike others, Japan (-0.156), France (-0.545), and Germany (-0.587) are yielding negative prices on average. The result based on median also provides approximately the same story. It implies that the distribution possibly symmetrical. The maximum value government bond yield price reached at 6.76 basis point in Russia, followed by India (5.15), Brazil (4.37), and Canada (4.197) while the minimum value reached at -0.746 in Germany, followed by France, Japan, UK, and the US during Covid-19 pandemic. Based on standard deviation, the financial market of India, followed by Brazil, Canada, Russia, and the US is most volatile than Germany, UK, and China during Covid-19 pandemic.

Table-1. Descriptive statistics.

\begin{tabular}{c|c|c|c|c|c|c|c|c|c|c}
\hline Sta/Vari. & US & UK & Japan & Germany & France & Canada & China & India & Russia & Brazil \\
\hline Mean & 0.604 & 0.333 & -0.156 & -0.587 & -0.545 & 0.746 & 1.890 & 4.205 & 5.508 & 3.399 \\
\hline Median & 0.157 & 0.261 & -0.129 & -0.575 & -0.536 & 0.265 & 2.078 & 4.168 & 5.755 & 3.385 \\
\hline Max. & 1.587 & 0.767 & -0.079 & -0.498 & -0.451 & 4.197 & 2.48 & 5.15 & 6.76 & 4.37 \\
\hline Min. & -0.046 & -0.094 & -0.438 & -0.746 & -0.724 & 0.175 & 1.14 & 2.7 & 4.23 & 2.051 \\
\hline Std.Dev. & 0.655 & 0.285 & 0.075 & 0.057 & 0.053 & 0.702 & 0.432 & 0.797 & 0.659 & 0.769 \\
\hline
\end{tabular}

\footnotetext{
${ }^{7}$ https://www.investing.com/rates-bonds/world-government-bonds
} 


\section{DATA DESCRIPTION}

This empirical analysis is based on daily data of top ten economies (mentioned in Table 2) by their gross domestic product during Covid-19 pandemic (from $1^{\text {st }}$ January to $10^{\text {th }}$ July 2020). Daily data implies from Monday to Friday. The study does not consider data on Saturday and Sunday to minimize the missing value in dataset. Practically, data on Saturday and Sunday are hardly available. Apart from this, if any missing value to be found in the series filled by simply taking 4 days' average (consecutive 4days from the backward of missing value position). The detail about the number of variables used for the analysis and their source are given in Table 2.

Table-2. Variables used and its source.

\begin{tabular}{l|l|l}
\hline Country & Variables & Data source \\
\hline US, UK Japan, Germany, France, & 3-months government bond yield price \\
Canada, India, Russia, Brazil & $\begin{array}{l}\text { 6-month government bond yield price } \\
\text { 1-year government bond yield price } \\
\text { 5-year government bond yield price } \\
\text { 10-year government bond yield price }\end{array}$ & Investing.com \\
\hline China & 1-year government bond yield price \\
& 2-year government bond yield price \\
& 5-year government bond yield price \\
& 7-year government bond yield price \\
& $10-$ year government bond yield price \\
\hline
\end{tabular}

\section{FORMATION OF COMPOSITE FINANCIAL SECTOR INDEX (FSI)}

For robustness check of empirical findings, the study constructs the financial sector index for every individual country. Following the paper of Batuo, Guidi, and Mlambo (2010), Hye (2011) and Younsi and Bechtini (2018) I made a composite financial sector index for the US, UK, Japan, Germany, France, Canada, China, India, Russia, and Brazil economies by applying principal component analysis (PCA) and the variables in model include; 6-months bond yield price (6MBYP), 1-year bond yield price(1YBYP), 5-years bond yield price(5YBYP), and 10-years bond yield price(10YBYP), for China, 2-year (2YBYP), 5-year (5YBYP), 7-year (7YBYP), and 10-year bond yield price(10YBYP). The PCA is a multivariate statistical method generally employed for analyzing the intercorrelation connecting many quantitative variables of interest (Younsi \& Bechtini, 2018). The PCA technique is found to be useful for building up a composite index (OECD/JRC, 2008) . Methodologically, for each dataset with "p" quantitative variables of interest, it can be evaluated at most "p" principal components (PC). Each PC is a linear combination of the original variables of interest where the coefficients are equal to the eigenvectors of correlation covariance matrix. The PC is then organized in a descending sequence of eigenvalues which are equal to variance of components.

The estimated result of the financial sector index (FSI) for all the sample countries through PCA method is reported in Table A1 in Appendix 1. The analysis of PC for Brazil shows that it explains 59.14\%, 40.35\%, 0.35\%, and $0.17 \%$ of standardized variance for the first, second, third, and fourth PC respectively. It means that I select the first PC to frame the financial sector index. The first PC is the result of a linear combination of four-measure of the financial sector with weights provided by the first eigenvector. However, the final index can be presented as follows;

$$
\mathrm{FSI}=6 \mathrm{MBYP}^{*} \mathrm{~W}_{1}+1 \mathrm{YBYP}^{*} \mathrm{~W}_{2}+5 \mathrm{YBYP}^{*} \mathrm{~W}_{3}+10 \mathrm{YBYP}^{*} \mathrm{~W}_{4}
$$

\footnotetext{
8 https://www.investing.com/rates-bonds/world-government-bonds

${ }_{9} \mathrm{OECD} / \mathrm{JRC}$ (2008) Handbook on constructing composite indicators: methodology and user guide. This handbook provides an extensive idea about how to frame a
} composite index involving various methods. 
Rescaling, the individual contribution of each series to the standardized variance of the first PC is approximately $53.57 \%, 56.76 \%, 53.75 \%$, and $31.92 \%$ respectively and I normalized these values which are around $27.33 \%\left(\mathrm{~W}_{1}\right)$, 28.95\% $\left(\mathrm{W}_{2}\right), 27.42 \%\left(\mathrm{~W}_{3}\right)$, and $16.28 \%\left(\mathrm{~W}_{4}\right)$ respectively. I used these normalized values as a weight to build the composite financial sector index for Brazil, represented by Eq. 1. The similar procedure I followed for rest of the countries under consideration (given in Table A1 in Appendix 1).

\section{CORRELATION ANALYSIS}

Table-3. Correlation Matrix of 3-months bond yield price.

\begin{tabular}{|c|c|c|c|c|c|c|c|c|c|c|}
\hline \multicolumn{11}{|c|}{ Correlation Matrix of 3-months bond yield price } \\
\hline Vari. & US & UK & Japan & Germany & France & Canada & China & India & Russia & Brazil \\
\hline US & 1 & & & & & & & & & \\
\hline UK & 0.915 & 1 & & & & & & & & \\
\hline Japan & 0.204 & -0.114 & 1 & & & & & & & \\
\hline Germany & -0.055 & -0.339 & 0.552 & 1 & & & & & & \\
\hline France & -0.529 & -0.607 & 0.264 & 0.344 & 1 & & & & & \\
\hline Canada & 0.940 & 0.901 & 0.077 & -0.109 & -0.538 & 1 & & & & \\
\hline China & 0.646 & 0.585 & 0.069 & -0.132 & -0.547 & 0.609 & 1 & & & \\
\hline India & 0.797 & 0.943 & -0.348 & -0.479 & -0.601 & 0.819 & 0.503 & 1 & & \\
\hline Russia & 0.482 & 0.740 & -0.522 & -0.620 & -0.427 & 0.528 & 0.121 & 0.855 & 1 & \\
\hline Brazil & 0.783 & 0.927 & -0.324 & -0.452 & -0.572 & 0.801 & 0.370 & 0.963 & 0.894 & 1 \\
\hline
\end{tabular}

Table 3 presents the correlation matrix of 3-months bond yield price of various countries during Covid-19 pandemic. The highest pairwise correlation is between India and Brazil, at 96.3\%. Japan has the least average pairwise correlation with other countries. Interestingly, figure shows a significant correlation among bond yield prices in different countries under study. For all sample economies, although to varying degrees, there is an increasing degree of a correlation either negatively or positively, possibly following Covid-19 pandemic globally. Specifically, the correlation of the US's, UK's, France's and Canada's bond yield price are very high with others except for Japan and Germany. The bond yield price of France is negatively correlated while that of the US, UK, and Canada are positively correlated to others. Similarly, bond yield price of China, India, Russia, and Brazil, on the other hand, is highly correlated with other financial markets. However, bond yield price of Japan is least correlated with others and then followed by Germany during Covid-19 pandemic.

\section{METHODOLOGY}

To measure the magnitude and direction of financial shock spillover during Covid-19, I employed VAR based Diebold and Yilmaz (2012) approach. It allows us to estimate the fraction of h-step ahead error variance for forecasting $Z_{i}$ which is due to $Z_{j}, \forall j \neq i$ for each $i$. Diebold and Yilmaz (2012) recommended an application of a generalized VAR model of Koop, Pesaran, and Potter (1996) and Pesaran and Shin (1998).

The own variance share indicates a fraction of h-step ahead error variance in forecasting $Z_{j}$ due to shocks in $Z_{j}$, for $j=1,2,---\mathrm{N}$, and cross variance share represents the fraction of h-step ahead error variances in forecasting $Z_{j}$ due to shocks in $Z_{i}$, for $i_{j} j=1,2,----N$ where $i \neq j$. This method can be 
understood well from Table 4. The NXN block in the following Table 4 known as variance decomposition matrix noted as $\left[T_{i j}^{h}\right]$.

Table-4. Financial shocks spillover Table.

\begin{tabular}{|c|c|c|c|c|c|}
\hline Variables & $Z_{1}$ & $Z_{2}$ & $\cdot \cdot \cdot \cdot$ & $Z_{N}$ & From others \\
\hline$Z_{1}$ & $T_{11}^{\text {h }}$ & $T_{12}^{\mathrm{h}}$ & $\cdot \cdot \cdot \cdot$ & $T_{1 N}^{h}$ & $\sum_{j=1}^{W} T_{1 j}^{\mathrm{h}} \times j \neq 1$, \\
\hline$Z_{2}$ & $T_{21}^{\text {hi }}$ & $T_{22}^{h}$ & . . & $T_{2 \mathrm{~N}}^{\mathrm{h}}$ & $\sum_{j=1}^{W} T_{2 j}^{h}, j \neq 2$, \\
\hline$x$ & $x$ & $=$ & & & \\
\hline$\therefore$ & $\therefore$ & $\begin{array}{l}= \\
\end{array}$ & $\therefore$ & $\therefore$ & $\therefore$ \\
\hline$Z_{N}$ & $T_{N 1}^{\text {h h }}$ & $T_{N 2}^{\text {hh }}$ & . . & $T_{N N}^{h^{h}}$ & $\sum_{j=1}^{N} T_{N j}^{h}, j \neq N$ \\
\hline To others & $\begin{array}{c}\sum_{i=1}^{N} T_{i,}^{j} \\
i \neq 1,\end{array}$ & $\begin{array}{l}U_{\mathrm{i}=1}^{\mathrm{N}} \mathrm{T}_{\mathrm{i} 2}^{\mathrm{h}} \\
\mathrm{i} \neq 2\end{array}$ & & $\sum_{\mathrm{i}=1}^{\mathrm{N}} \mathrm{T}_{\mathrm{iN}}^{\mathrm{h}}$ & $\frac{1}{N} \sum_{j=1}^{N} T_{i j}^{h}, j \neq i$ \\
\hline Including own & $\sum_{\mathrm{i}=1}^{N} T_{i}$ & $S_{i=1}^{N} T_{i 2}^{h}$ & & $\sum_{i=1}^{N} T_{i N}^{h}$ & Total spillover (TS) \\
\hline
\end{tabular}

The second last bottom row (named as 'To others') elements represent column sums except for own element in that column. The rightmost column (named as 'from others') represents row sum, except for own element in that row and a bottom right element represents a total spillover. The diagonal elements represent own innovations and off-diagonal elements represent innovations from others. Marking the KPPS (Koop et al., 1996) h-step ahead

forecast error variance decomposition by $\Theta_{j i}^{g}(\mathrm{~h})$, for $\mathrm{h}=1,2,-\cdots$

$$
\Theta_{j i}^{g}(\mathrm{~h})=\frac{\sigma_{j j}^{-1} \sum_{i=0}^{H-1}\left(e_{j}^{f} \Pi_{h} \Sigma_{\varepsilon} \theta_{i}\right)^{2}}{\sum_{h=0}^{H-1}\left(\theta_{j}^{g} \Pi_{h} \Sigma_{\varepsilon} \Pi_{h i}^{t} \theta_{j}\right)}
$$

Where $\Sigma$ is a variance matrix for error vector ${ }^{\prime} \varepsilon, \sigma_{j j}$ is a standard deviation of error term for $j^{\text {th }}$ equation, $e_{j}$ is the selection vector with one as $j^{t h}$ element and zero otherwise in Eq. 2 . It can be given as $\sum_{i=1}^{N} \Theta_{j i}^{g}(h) \neq 1$, means a sum of the elements of each row of variance decomposition table is not equal to 1, because of non-zero covariance between original shocks. Now, we can normalize $\Theta_{j i}^{g}(\mathrm{~h})$ by dividing it by row sum and reduced as:

\footnotetext{
${ }_{10}$ The Equation 1 is derived from generalised impulse response function of Koop et al. (1996) and Pesaran and Shin (1998).
} 


$$
\widehat{\Theta_{j i}} g(h)=\frac{\sigma_{j i}^{g}(h)}{\sum_{i=1}^{N} \sigma_{j i}^{g}(h)}
$$

By construction $\sum_{i=1}^{N} \widehat{\Theta}_{j i}^{g}(h)=1$ and $\sum_{j i=1}^{N} \widehat{\Theta}_{j i}^{g}(h)=\mathrm{N}$ in Equation 3

The spillover index is the cross-variance shares gained from the table and marked as:

$$
S^{g}(\mathrm{~h})=\frac{\sum_{\substack{j=1 \\ j \neq i}}^{N} \widehat{\theta}_{j i}^{g}(h)}{\sum_{j i=1}^{N} \widehat{Q} \frac{g}{j i}(h)} \times 100=\frac{\sum_{\substack{j=1 \\ j \neq 1}}^{N} \widehat{\theta}_{j i}^{g}(h)}{N} \times 100
$$

Like Cholesky factor-based measure of KPSS used in Diebold and Yilmaz (2012). Equation 4 shows the total spillover index total forecast error variance due to mutual contact among countries or variables. Diebold and Yilmaz estimate the size of spillover received by market $j$ from all other markets $i$ expressed as in Equation 5:

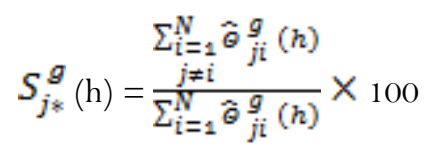

Similarly, the size of spillover from the market $j$ to all other markets $i$ expressed as in Equation 6:

$$
S_{* j}^{g}(\mathrm{~h})=\frac{\sum_{i=1}^{N} \hat{\theta}_{i j}^{g}(h)}{\sum_{i=1}^{N} \hat{\theta}_{i j}^{g}(h)} \times 100
$$

Note that spillover size provides a decomposition of total spillover into those coming from (or to) a particular source. The estimation procedure of net spillover from market $j$ to all other markets $i$ as in Equation 7

$$
S_{j}^{g}(\mathrm{~h})=S_{i j}^{g}(\mathrm{~h})-S_{j i}^{g}(\mathrm{~h})
$$

The net spillover is the difference between gross spillover "to" and gross spillover received "from" all other markets. More specifically, Equation 6 minus Equation 5 provides net spillover. Note all the variables in model are endogenous.

\section{DISCUSSION OF EMPIRICAL RESULTS}

The empirical model estimated is stable. Figure 3 shows the estimated model is stable with lag 2 selected by Akaike information Criteria. As no root lies outside the unit circle, our model satisfies stability conditions.

The baseline model (3-months bond yield price) follows a VAR (2) and $\mathrm{H}=10$. Table 5 summarizes the estimated results. The total financial sector innovations spillover for full sample is $49.20 \%$, meaning that approximately one-half of the total variance of forecast errors for ten countries under study is explained by spillover innovations across countries, and roughly one-half of this variance is then explained by idiosyncratic economy specific innovations during Covid-19 pandemic from $1^{\text {st }}$ January to $10^{\text {th }}$ July 2020. 


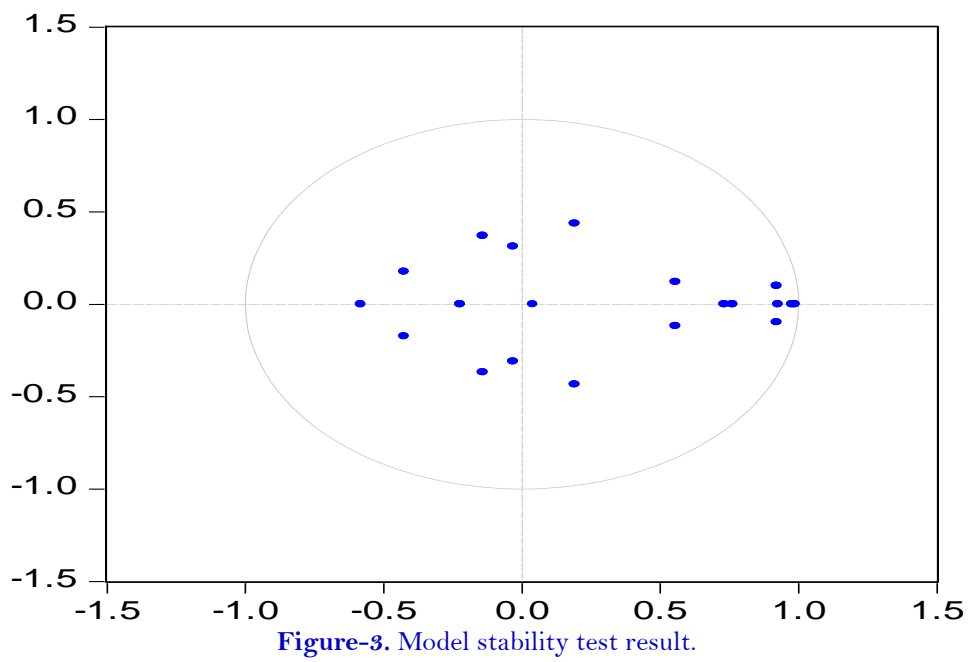

Table-5. Financial shocks Spillover (3-month bond yield price).

\begin{tabular}{c|c|c|c|c|c|c|c|c|c|c|c}
\hline \multicolumn{10}{c}{ Spillover (Connectedness) Table } \\
\hline Variables & US & UK & Japan & Germany & France & Canada & China & India & Russia & Brazil & $\begin{array}{c}\text { From } \\
\text { Others }\end{array}$ \\
\hline US & 55.1 & 3.1 & 15.4 & 0.3 & 10.7 & 2.3 & 1.7 & 3.1 & 8.2 & 0.1 & 44.9 \\
\hline UK & 22.8 & 42 & 6.6 & 3.6 & 0.6 & 0.2 & 2.2 & 1.8 & 12.4 & 7.7 & 57.9 \\
\hline Japan & 21.1 & 0.7 & 40.3 & 1.8 & 19.8 & 1.5 & 1.3 & 5.9 & 5.2 & 2.3 & 59.7 \\
\hline Germany & 14.6 & 2.7 & 5.8 & 41.8 & 8.4 & 1.6 & 4.9 & 10 & 5.3 & 4.8 & 58.2 \\
\hline France & 0.3 & 0.6 & 5.3 & 0.6 & 65.5 & 2.4 & 2.5 & 2.6 & 6.5 & 13.8 & 34.5 \\
\hline Canada & 26.2 & 2.5 & 5.3 & 0.1 & 3.4 & 57.2 & 0.6 & 0.8 & 3.7 & 0.2 & 42.8 \\
\hline China & 0.8 & 2.7 & 0.8 & 3.4 & 0.7 & 0.5 & 75.7 & 7.1 & 6.9 & 1.3 & 24.3 \\
\hline India & 4.4 & 1.6 & 3.1 & 9.2 & 12.2 & 0.7 & 2.2 & 46.2 & 9.9 & 10.5 & 53.8 \\
\hline Russia & 1.6 & 0.7 & 1.9 & 7.1 & 17.8 & 1.7 & 5.4 & 4.7 & 29.7 & 29.5 & 70.3 \\
\hline Brazil & 4.9 & 7.7 & 2.3 & 2.4 & 7.5 & 0.2 & 4.2 & 2.8 & 14 & 54 & 46 \\
\hline to others & 96.6 & 22 & 46.6 & 28.4 & 81.1 & 11.1 & 25.1 & 38.9 & 72.1 & 70.3 & TS=49.20\% \\
\hline Net & 51.7 & -35.9 & -13.1 & -29.8 & 46.6 & -31.7 & 0.8 & -14.9 & 1.8 & 24.3 & \\
\hline
\end{tabular}

Note: This table indicates the spillover table for the period $1^{\text {st }}$ January 2020 to $10^{\text {th }}$ July 2020 . The model estimation follows a VAR (2) and H=10. The column demonstrate the fraction of forecast error variance that the headline country exports to all countries. The rows demonstrate the fraction of forecast error variance that the headline country imports from all countries. The row net indicates the difference between "To Others" and "From Others". The Total spillover (TS) is the average of all off-diagonal elements, equals to $49.11 \%$. This model estimation is based on 3-months bond yield price of all countries.

The US, followed by France, Russia, and Brazil contributed the most to the variance of forecast error of rest of the countries, as shown by "To Other" row in table 5. The biggest net exporters (To Others-From Others) of financial innovation are the US and then followed by France, Brazil, Russia, and China. On the other hand, the UK, Canada, Germany, India, and Japan are all net importers of financial sector innovations. Interestingly, China is the most quarantined country in this group of sample economies, with most of its financial shocks being driven by its own domestic financial innovations. China also explains the insignificant amount of variance of forecast errors of other financial markets. Similarly, it also receives the least magnitude of the variance of forecast errors from other countries.

\subsection{Visualization of Direction of Financial Innovations Spillover}

Figure 4 demonstrates the financial sector innovations spillover network among different financial markets (countries). This network analysis shows a higher amount of financial innovations Brazil export to Russia, followed by the US export to Canada, the UK, and Japan, France export to Japan and Russia, Japan export to the US. Examination of the financial market shocks spillover network allows us to extricate the relative magnitude of directional "To Others" and "From Others" interlinkage of financial market shocks spillover during Covid-19 pandemic. 


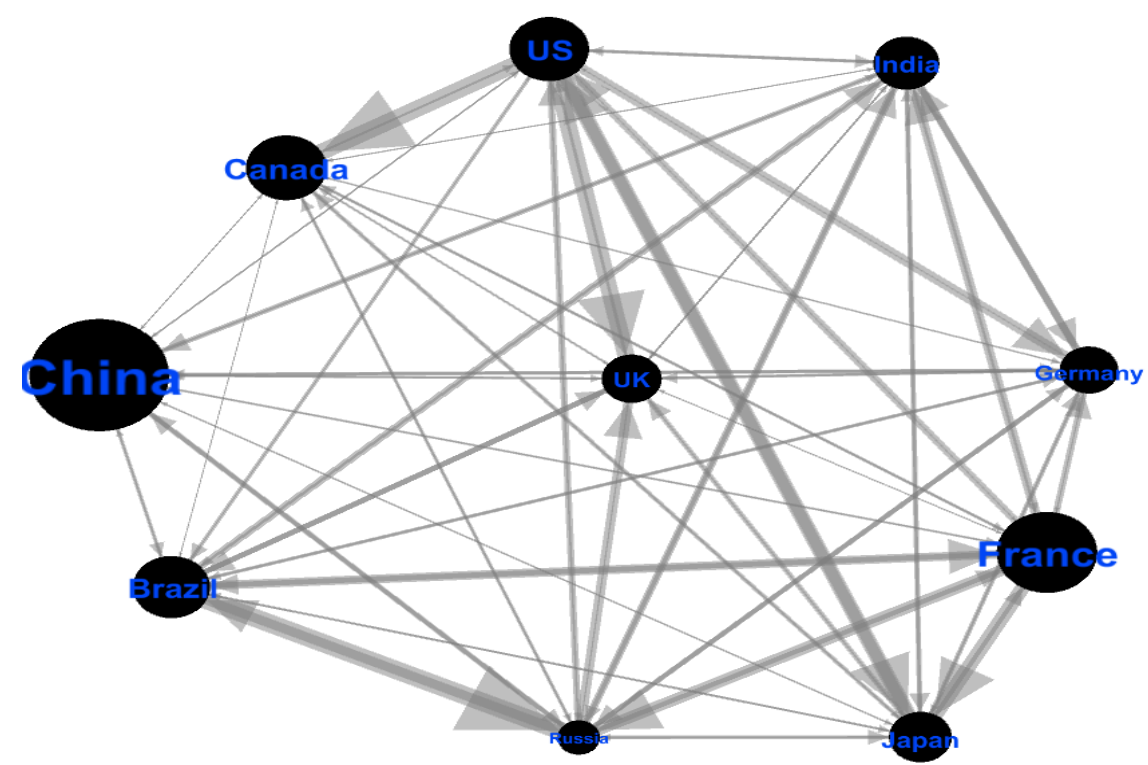

Figure-5. Directional financial shocks spillover.

Note: Figure 4 shows pairwise directional spillover of financial market shocks during Covid-19 pandemic (from $1^{\text {st }}$ January to $10^{\text {th }}$ July 2020 ). It shows bidirectional spillover among countries. Circles in figure are known as nodes. Bigger is the node, higher is the own financial market innovations and lesser is the foreign financial market innovations. Smaller is the node, higher is the foreign financial market innovations and lesser is the own financial innovations. The connectivity lines in figure are known as edges. Wider is the visibility of edges, larger is the degree of spillover while narrower is the visibility of edges, lower is the degree of spillover between countries. Note that this figure is based on the financial innovations spillover Table 5 .

\section{ROBUSTNESS CHECK}

For robustness check of empirical findings, the study constructed the financial sector index (FSI) ${ }^{11}$ for every individual country (For FSI, see section 5 for detail). The estimated model to check robustness is also stable (See Figure A1 in Appendix 1). The total financial sector shocks spillover for full sample is $62 \%$, meaning that approximately more than $3 / 5^{\text {th }}$ of the total variance of forecast errors for ten countries under study is explained by innovations spillover across countries. This estimated figure is marginally higher compared to baseline model estimated figure (See Table A2 in Appendix 1). According to baseline model (3- months bond yield price), the total spillover is $49,20 \%$, but the model estimated to check robustness is based on composite financial sector index according to which total spillover is $62 \%$. The marginal variation in empirical results between two models is for the following reasons; (i) latter model (index-based model) is based on a composite index which captures a broader picture of spillover, and (ii) spillover is higher with long terms bond yield price which incorporated in the latter model. Sowmya, Prasanna, and Bhaduri (2016) strongly said that spillover is higher with long term bond yield compared to short term bond yield because the long-term rates are influenced by the preference of global investors and the global financial conditions.

However, Akhtaruzzaman et al. (2020) examine how financial contagion happens viz financial and financial firms between China and G7 economies during Covid-19. They found that financial (nonfinancial) returns and volatility spillover are, on average, 61.99\% (64.09\%) and 60.13\% (65.51\%) respectively. For the analysis, Akhtaruzzaman et al. (2020) used USD denominated return indices representing financial markets while this study used government bond yield price to presents the financial market. The estimated results of this analysis resemble the findings of Akhtaruzzaman et al. (2020) during Covid-19 pandemic. The empirical findings suggest that the financial shocks spillover among the US, UK, Japan, Germany, France, Canada, China, India, Russia, and Brazil economies during Covid-19 is high.

\footnotetext{
${ }_{11}$ The composite index captured broader information regarding financial shocks spillover. The composite index can recapitulate complex, multi-dimensional realities and broader perspective than unidimensional indicators and thus, make it possible to incorporate larger information in the sphere of analysis (OECD/JRC, 2008).
} 


\section{CONCLUSION}

To understand financial market responses and its agents comprehensively, this paper aims to assess the magnitude of cross-country financial spillover and its direction during Covid-19 pandemic (from $1^{\text {st }} \mathrm{January}$ to $10^{\text {th }}$ July 2020) among top ten economies such as the US, China, Japan, Germany, India, UK, France, Brazil, Canada, and Russia. Employing Diebold and Yilmaz (2012) VAR based spillover approach, the study found that the financial sector innovations spillover is high during Covid-19 pandemic. This finding is also supported by the argument of Akhtaruzzaman et al. (2020). The total financial sector innovations spillover for full sample is $49.20 \%$, and when it is measured through a composite index, total spillover is $62 \%$, on average, meaning that approximately one-half of the total variance of forecast errors for ten countries under study is explained by the spillover of innovations across countries. The marginal variation in empirical results between two models is for the following reasons specifically; (i) latter (index-based model) model is based on a composite index which capture a broader picture of spillover, and (ii) spillover is higher with long terms bond yield price which incorporated in latter model.

Funding: This study received no specific financial support.

Competing Interests: The author declares that there are no conflicts of interests regarding the publication of this paper.

Acknowledgement: I thank the Centre for Development Studies (CDS) for providing an exciting and cordial research environment where I advanced this analysis.

\section{REFERENCES}

Abdul, A., \& Mia, A. (2020). The economic impact of the COVID-19 outbreak on developing Asia. Retrieved from: https://www.adb.org/sites/default/files/publication/571536/adb-brief-128-economic-impact-covid19-developingasia.pdf.

Abiad, A., Arao, R. M., \& Dagli, S. (2020). The economic impact of the COVID-19 outbreak on developing Asia. ADB Briefs, No. 128, 6 March 2020. Available at: http://dx.doi.org/10.22617/BRF200096.

Akhtaruzzaman, M., Boubaker, S., \& Sensoy, A. (2020). Financial contagion during COVID-19 crises. Finance Research Letters, 101604. Available at: 10.1016/j.frl.2020.101604.

Albulescu, C. (2020). Coronavirus and financial volatility: 40 days of fasting and fear. ArXiv preprint arXiv: 2003.04005. Retrieved from: https://arxiv.org/.

Ali, M., Alam, N., \& Rizvi, S. A. R. (2020). Coronavirus (COVID-19)-An epidemic or pandemic for financial markets. Journal of Behavioral and Experimental Finance, 100341.

Antonakakis, N., \& Vergos, K. (2013). Sovereign bond yield spillovers in the Eurozone during the financial and debt crisis. Journal of International Financial Markets, Institutions, and Money, 2013(26), 258-272. Available at: https://doi.org/10.1016/j.intfin.2013.06.004.

Baker, S. R., Bloom, N., Davis, S. J., Kost, K. J., Sammon, M. C., \& Viratyosin, T. (2020). The unprecedented stock market impact of COVID-19 (No. w26945). National Bureau of Economic Research.

Barua, S. (2020). Understanding coronanomics: The economic implications of the coronavirus (COVID-19) pandemic. MPRA Paper No. 99693, posted 20 Apr 2020 07:49 UTC, Retrieved from: https://mpra.ub.uni-muenchen.de/99693/.

Batuo, M. E., Guidi, F., \& Mlambo, K. (2010). Financial development and income inequality: Evidence from African countries. MPRA Paper No. 25658, posted 11 Oct 2010 18:58 UTC. Retrieved from: https://mpra.ub.uni-muenchen.de/25658/.

Board, F. S. (2020). COVID-19 pandemic: Financial stability implication and policy measures taken. Retrieved from: https://www.fsb.org/2020/07/covid-19-pandemic-financial-stability-implications-and-policy-measures-taken-reportto-the-g20/.

Chevallier, J., \& Ielpo, F. (2013). Volatility spillovers in commodity markets. Applied Economics Letters, 20(13), 1211 1-1227.

Corbet, S., Hou, Y., Hu, Y., Lucey, B., \& Oxley, L. (2020). Aye corona! the contagion effects of being named Corona during the COVID-19 pandemic. Finance Research Letters, 101591 . Available at: https://doi.org/10.1016/j.frl.2020.101591. 
Corbet, S., Larkin, C., \& Lucey, B. (2020). The contagion effects of the covid-19 pandemic: Evidence from gold and cryptocurrencies. Finance Research Letters, 35, 101554. Available at: https://doi.org/10.1016/j.frl.2020.101554.

Cronin, D. (2014). The interaction between money and asset markets: A spillover index approach. Journal of Macroeconomics, 39, 185-202. Available at: https://doi.org/10.1016/j.frl.2020.101554.

Diebold, F. X., \& Yilmaz, K. (2012). Better to give than to receive: Predictive directional measurement of volatility spillovers. International Journal of Forecasting, 28(1), 57-66. Available at: https://doi.org/10.1016/j.ijforecast.2011.02.006.

Goodell, J. W. (2020). COVID-19 and finance: Agendas for future research. Finance Research Letters, 35, 101512. Available at: https://doi.org/10.1016/j.frl.2020.101512.

Gurría, A. (2020). Coronavirus (Covid-19): joint actions to win the war. OCDE. Disponibleen: https:/ / www.oecd.org/about/secretary-general/Coronavirus-COVID-19-Joint-actions-towin-the-war.pdf.

Hye, Q. M. A. (2011). Financial development index and economic growth: Empirical evidence from India. Journal of Risk Finance, 12(2), 98-111. Available at: https://doi.org/10.1108/15265941111112820.

Klößner, S., \& Sekkel, R. (2014). International spillovers of policy uncertainty. Economics Letters, 124(3), 508-512.

Klößner, S., \& Wagner, S. (2014). Exploring all VAR orderings for calculating spillovers? Yes, we can! —a note on Diebold and Yilmaz (2009). Journal of Applied Econometrics, 29(1), 172-179. Available at: https://doi.org/10.1002/jae.2366.

Koop, G., Pesaran, M. H., \& Potter, S. M. (1996). Impulse response analysis in nonlinear multivariate models. Journal of Econometrics, 74(1), 119-147. Available at: https://doi.org/10.1016/0304-4076(95)01753-4.

Kumar, M. (2013). Returns and volatility spillover between stock prices and exchange rates: Empirical evidence from IBSA countries. International Journal of Emerging Markets, 8(2), 108-128. Available at: https://doi.org/10.1108/17468801311306984.

Maliszewska, M., Mattoo, A., \& Van Der Mensbrugghe, D. (2020). The potential impact of COVID-19 on GDP and trade: A preliminary assessment. Policy Research Working Paper 9211.

McKibbin, W. J., \& Fernando, R. (2020). The global macroeconomic impacts of COVID-19: Seven Scenarios.

OECD/JRC. (2008). Handbook on constructing composite indicators: Methodology and user guide. Paris: OECD Publishing.

Ozili, P. K., \& Arun, T. (2020). Spillover of COVID-19: Impact on the global economy. MPRA Paper No. 99850, posted 26 Apr 2020 08:37 UTC. Retrieved from: https://mpra.ub.uni-muenchen.de/99850/.

Pesaran, H. H., \& Shin, Y. (1998). Generalized impulse response analysis in linear multivariate models. Economics Letters, 58(1), 17-29. Available at: https://doi.org/10.1016/s0165-1765(97)00214-0.

Shehzad, K., Xiaoxing, L., \& Kazouz, H. (2020). COVID-19's disasters are perilous than Global Financial Crisis: A rumor or fact? Finance Research Letters, 101669. Available at: https://doi.org/10.1016/j.frl.2020.101669.

Sowmya, S., Prasanna, K., \& Bhaduri, S. (2016). Linkages in the term structure of interest rates across sovereign bond markets. Emerging Markets Review, $100(27), 118-139$. Available at: https://doi.org/10.1016/j.ememar.2016.05.001.

Urbina, J. (2013). Financial spillovers across countries: Measuring shock transmissions. MPRA Paper No. 75756 . Retrieved from: https://mpra.ub.uni-muenchen.de/ 75756 .

Younsi, M., \& Bechtini, M. (2018). Economic growth, financial development, and income inequality in BRICS countries: Evidence from panel Granger causality tests. MPRA Paper No. 85182, posted 14 Mar 2018 12:36 UTC. Retrieved from: https://mpra.ub.uni-muenchen.de/85182/. 
APPENDIX 1

Table-A1: Construction of financial sector index (FSI) for Brazil, Canada, China, France, Germany, Japan, India, Russia, UK, and the US.

\begin{tabular}{|c|c|c|c|c|c|c|c|c|c|c|}
\hline \multirow[t]{2}{*}{ Brazil } & \multicolumn{5}{|c|}{ Eigenvalues(Sum=4, Average-1) } & \multicolumn{5}{|c|}{ Eigenvectors(loading) } \\
\hline & No. & Value & Difference & Proportion & Cumulative proportion & Variables & PC1 & PC2 & PC3 & PC4 \\
\hline & 1 & 2.3654 & 0.7516 & 0.5914 & 0.5914 & 6-MBY & 0.5357 & -0.443 & 0.3725 & -0.614 \\
\hline & 2 & 1.6138 & 1.5998 & 0.4035 & 0.9948 & $1-\mathrm{YBY}$ & 0.5676 & -0.380 & -0.070 & 0.7264 \\
\hline & 3 & 0.0139 & 0.0072 & 0.0035 & 0.9983 & 5 -YBY & 0.5375 & 0.4381 & -0.673 & -0.255 \\
\hline & 4 & 0.0067 & - & 0.0017 & 1.0000 & 10-YBY & 0.3192 & 0.6831 & 0.6831 & 0.1702 \\
\hline \multicolumn{11}{|l|}{ Canada } \\
\hline & 1 & 3.8921 & 3.80882 & 0.9730 & 0.9730 & 6-MBY & 0.4953 & 0.6831 & 0.5364 & 0.0182 \\
\hline & 2 & .0832821 & .0613254 & 0.0208 & 0.9938 & $1-Y B Y$ & 0.5016 & 0.2721 & -0.813 & 0.1121 \\
\hline & 3 & .0219566 & .0192963 & 0.0055 & 0.9993 & 5 -YBY & 0.5031 & -0.400 & 0.0712 & 0.1121 \\
\hline & 4 & .0026603 & - & 0.0007 & 1.0000 & 10-YBY & 0.5000 & -0.546 & 0.2131 & 0.6368 \\
\hline \multicolumn{11}{|l|}{ China } \\
\hline & 1 & 3.8355 & 3.70047 & 0.9589 & 0.9589 & 2-YBY & 0.4961 & -0.617 & 0.3727 & 0.4841 \\
\hline & 2 & .135026 & .112447 & 0.0338 & 0.9926 & 5 -YBY & 0.5061 & -0.309 & -0.160 & -0.789 \\
\hline & 3 & .0225793 & .0156802 & 0.0056 & 0.9983 & 7-YBY & 0.5050 & 0.2548 & -0.735 & 0.3733 \\
\hline & 4 & .00689906 & - & 0.0017 & 1.0000 & 10-YBY & 0.4928 & 0.6774 & 0.5429 & -0.059 \\
\hline \multicolumn{11}{|l|}{ Germany } \\
\hline & 1 & 2.61522 & 1.42105 & 0.6538 & 0.6538 & 6-MBY & 0.4222 & 0.6234 & 0.6578 & 0.0197 \\
\hline & 2 & 1.19418 & 1.0331 & 0.2985 & 0.9524 & 1-YBY & 0.5123 & 0.4344 & -0.740 & 0.0112 \\
\hline & 3 & .161082 & .131567 & 0.0403 & 0.9926 & 5 -YBY & 0.5228 & -0.474 & 0.0936 & 0.7017 \\
\hline & 4 & .0295152 & - & 0.0074 & 1.0000 & 10-YBY & 0.5348 & -0.444 & 0.0988 & -0.712 \\
\hline \multicolumn{11}{|l|}{ France } \\
\hline & 1 & 2.69417 & 1.50424 & 0.6735 & 0.6735 & 6-MBY & 0.4417 & 0.6201 & 0.1373 & 0.6337 \\
\hline & 2 & 1.11219 & 1.18993 & 0.2975 & 0.9710 & $1-Y B Y$ & 0.5451 & 0.3869 & -0.098 & -0.737 \\
\hline & 3 & .0777392 & .0395827 & 0.0194 & 0.9905 & 5 -YBY & 0.4921 & -0.509 & 0.7059 & 0.0025 \\
\hline & 4 & .0381565 & - & 0.0095 & 1.0000 & 10-YBY & 0.5154 & -0.454 & -0.687 & 0.2342 \\
\hline \multicolumn{11}{|l|}{ India } \\
\hline & 1 & 3.69128 & 3.50269 & 0.9228 & 0.9228 & 6-MBY & 0.5052 & -0.533 & 0.0238 & 0.6778 \\
\hline & 2 & .188589 & .0775892 & 0.0471 & 0.9700 & 1-YBY & 0.5092 & -0.444 & 0.0775 & -0.7326 \\
\hline & 3 & .111 & .101869 & 0.0278 & 0.9977 & 5 -YBY & 0.4912 & 0.5733 & 0.6528 & 0.0624 \\
\hline & 4 & .00913065 & - & 0.0023 & 1.0000 & 10-YBY & 0.4942 & 0.4342 & -0.753 & 0.0001 \\
\hline \multicolumn{11}{|l|}{ Japan } \\
\hline & 1 & 2.2235 & .71946 & 0.5559 & 0.5559 & 6-MBY & 0.2552 & 0.7043 & 0.6611 & -0.043 \\
\hline & 2 & 1.50404 & 1.25436 & 0.3760 & 0.9319 & $1-Y B Y$ & 0.4830 & 0.4893 & -0.6937 & 0.2145 \\
\hline & 3 & .249681 & .226902 & 0.0624 & 0.9943 & 5-YBY & 0.4830 & 0.4893 & -0.6937 & 0.2145 \\
\hline
\end{tabular}


Asian Development Policy Review, 2020, 8(4): 298-318

\begin{tabular}{|c|c|c|c|c|c|c|c|c|c|c|c|}
\hline & 4 & \multicolumn{2}{|c|}{.022779} & - & 0.0057 & 1.0000 & 10-YBY & 0.5576 & -0.430 & 0.2856 & 0.6498 \\
\hline \multicolumn{12}{|l|}{ Russia } \\
\hline & 1 & \multicolumn{2}{|c|}{3.74495} & 3.54094 & 0.9362 & 0.9362 & 6-MBY & 0.4879 & 0.6857 & 0.5192 & 0.1489 \\
\hline & 2 & \multicolumn{2}{|c|}{.204011} & .157615 & 0.0510 & 0.9872 & $1-Y B Y$ & 0.5052 & 0.2493 & -0.8234 & 0.0681 \\
\hline & 3 & \multicolumn{2}{|c|}{.0463958} & .0417534 & 0.0116 & 0.9988 & 5-YBY & 0.5106 & -0.309 & 0.1546 & -0.7872 \\
\hline & 4 & \multicolumn{2}{|c|}{.00464236} & - & 0.0012 & 1.0000 & 10-YBY & 0.4960 & -0.609 & 0.1688 & 0.5946 \\
\hline \multicolumn{12}{|l|}{ UK } \\
\hline & 1 & \multicolumn{2}{|c|}{3.79031} & 3.6439 & 0.9476 & 0.9476 & 6-MBY & 0.5006 & 0.4103 & -0.7547 & 0.1076 \\
\hline & 2 & \multicolumn{2}{|c|}{.14641} & .10191 & 0.0366 & 0.9842 & 1-YBY & 0.4967 & 0.5575 & 0.6516 & 0.1337 \\
\hline & 3 & \multicolumn{2}{|c|}{.0445004} & .0257177 & 0.0111 & 0.9953 & 5 -YBY & 0.5067 & -0.317 & 0.0494 & -0.8000 \\
\hline & 4 & \multicolumn{2}{|c|}{.0187827} & - & 0.0047 & 1.0000 & 10-YBY & 0.4959 & -0.648 & 0.0585 & 0.5749 \\
\hline \multicolumn{12}{|l|}{ US } \\
\hline & 1 & \multicolumn{2}{|c|}{3.94068} & 3.88807 & 0.9852 & 0.9852 & 6-MBY & 0.4990 & -0.592 & 0.1657 & 0.6109 \\
\hline & 2 & \multicolumn{2}{|c|}{.0526113} & .0468831 & 0.0132 & 0.9983 & 1-YBY & 0.5018 & -0.370 & 0.0445 & -0.7805 \\
\hline & 3 & \multicolumn{2}{|c|}{.00572823} & .00475213 & 0.0014 & 0.9998 & 5-YBY & 0.5014 & 0.3271 & -0.7916 & 0.1221 \\
\hline & 4 & \multicolumn{2}{|c|}{.000976104} & - & 0.0002 & 1.0000 & 10-YBY & 0.4978 & 0.6369 & 0.5864 & 0.0515 \\
\hline \multicolumn{12}{|c|}{ Normalized components } \\
\hline Number & \multicolumn{2}{|c|}{ Brazil } & Canada & China & France & Germany & India & Japan & Russia & UK & US \\
\hline 1 & \multicolumn{2}{|c|}{0.2733} & 0.2476 & 0.2480 & 0.2214 & 0.2119 & 0.2526 & 0.1434 & 0.2439 & 0.2503 & 0.2495 \\
\hline 2 & \multicolumn{2}{|c|}{0.2895} & 0.2508 & 0.2530 & 0.2733 & 0.2571 & 0.2546 & 0.2715 & 0.2526 & 0.2483 & 0.2509 \\
\hline 3 & \multicolumn{2}{|c|}{0.2742} & 0.2515 & 0.2525 & 0.2467 & 0.2624 & 0.2456 & 0.2715 & 0.2553 & 0.2533 & 0.2507 \\
\hline 4 & \multicolumn{2}{|c|}{0.1628} & 0.25 & 0.2464 & 0.2584 & 0.2684 & 0.2471 & 0.3134 & 0.2480 & 0.2479 & 0.2489 \\
\hline
\end{tabular}


Inverse Roots of AR Characteristic Polynomial

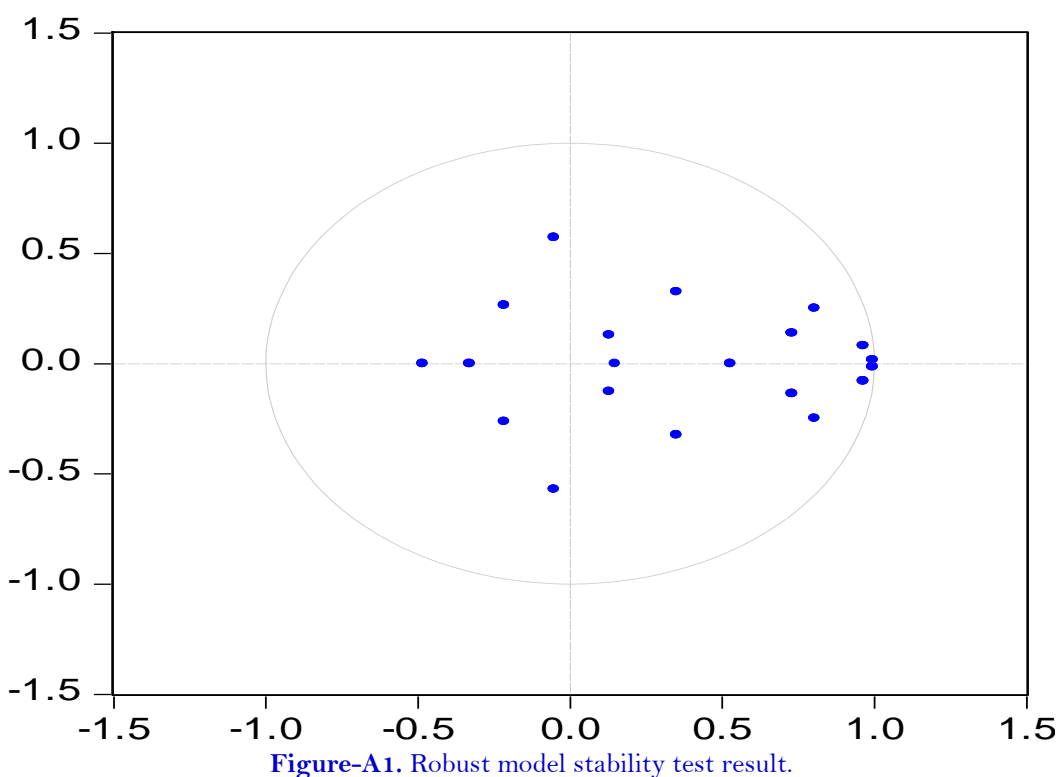

Note: The empirical model estimated is stable. Figure A1 demonstrates the estimated model is stable with lag 2 selected by Akaike information Criteria. As no root lies outside the unit circle, our robustness model satisfies the stability condition.

Table-A2. Robust financial innovations spillover model.

\begin{tabular}{|c|c|c|c|c|c|c|c|c|c|c|c|}
\hline \multicolumn{12}{|c|}{ Spillover (Connectedness) Table } \\
\hline Variable & $\begin{array}{c}\text { US } \\
\text { FSI }\end{array}$ & $\begin{array}{l}\text { UK } \\
\text { FSI }\end{array}$ & $\begin{array}{c}\text { Japan } \\
\text { FSI }\end{array}$ & $\begin{array}{c}\text { Germany } \\
\text { FSI }\end{array}$ & $\begin{array}{c}\text { France } \\
\text { FSI }\end{array}$ & $\begin{array}{c}\text { Canada } \\
\text { FSI }\end{array}$ & $\begin{array}{c}\text { China } \\
\text { FSI }\end{array}$ & $\begin{array}{c}\text { India } \\
\text { FSI }\end{array}$ & $\begin{array}{c}\text { Russia } \\
\text { FSI }\end{array}$ & $\begin{array}{c}\text { Brazil } \\
\text { FSI }\end{array}$ & $\begin{array}{c}\text { From } \\
\text { Others }\end{array}$ \\
\hline US FSI & 53.1 & 7.3 & 21.1 & 1 & 1.1 & 0.8 & 1 & 10.4 & 2.6 & 1.6 & 46.9 \\
\hline UK FSI & 24.6 & 26.4 & 5.1 & 7.9 & 7.5 & 0.6 & 3.1 & 6 & 16.5 & 2.1 & 73.6 \\
\hline Japan FSI & 21.1 & 5.2 & 52.1 & 1.6 & 4.1 & 2.1 & 1.3 & 5.4 & 6.8 & 0.4 & 47.9 \\
\hline $\begin{array}{c}\text { Germany } \\
\text { FSI }\end{array}$ & 23.3 & 10 & 27.7 & 13 & 13.8 & 1.5 & 0.5 & 3.8 & 5.9 & 0.4 & 87 \\
\hline France FSI & 8.5 & 7.6 & 21.6 & 9.1 & 22.6 & 1.8 & 1.1 & 6.2 & 18.8 & 2.7 & 77.4 \\
\hline Canada FSI & 44.3 & 9 & 17.1 & 1.4 & 1.4 & 10.1 & 1.8 & 9 & 4.6 & 1.4 & 89.9 \\
\hline China FSI & 5.4 & 0.2 & 5.7 & 0.2 & 0.8 & 2.1 & 80.9 & 0.7 & 0.8 & 3.2 & 19.1 \\
\hline India FSI & 9 & 0.3 & 1.2 & 10.5 & 2.7 & 0.3 & 0.7 & 49.2 & 15.1 & 10.9 & 50.8 \\
\hline Russia FSI & 7.8 & 9.6 & 9.9 & 16.5 & 6.4 & 0.6 & 1.1 & 5.6 & 35.7 & 6.7 & 64.3 \\
\hline Brazil FSI & 1.8 & 3.2 & 2.8 & 16.5 & 5 & 1.3 & 5 & 8.3 & 19 & 37.1 & 62.9 \\
\hline to others & 146 & 52.4 & 112.3 & 64.7 & 42.9 & 11.1 & 15.7 & 55.2 & 90.2 & 29.4 & $\mathrm{TS}=62 \%$ \\
\hline Net & 99.1 & -21.2 & 64.4 & -23.2 & -34.5 & -78.8 & -3.4 & 4.4 & 25.9 & -33.5 & \\
\hline
\end{tabular}

Note: This table indicates the robust financial shocks spillover based on financial sector index to check robustness of this empirical finding for the period $1^{\mathrm{s}}$

January 2020 to $10^{\text {th }}$ July 2020. The model estimation follows a VAR (2) and $\mathrm{H}=10$. The columns demonstrate the fraction of forecast error variance that the headline country exports to all countries. The rows demonstrate the fraction of forecast error variance that the headline country imports from all countries. The row net indicates the difference between "To Others" and "From Others". The TS is the average of all off-diagonal elements, equals to $62 \%$. 


\section{APPENDIX 2}

(a)

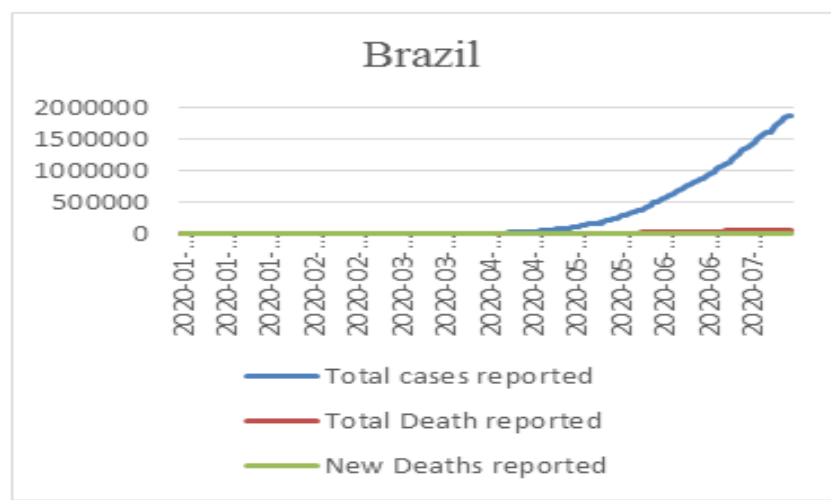

(c)

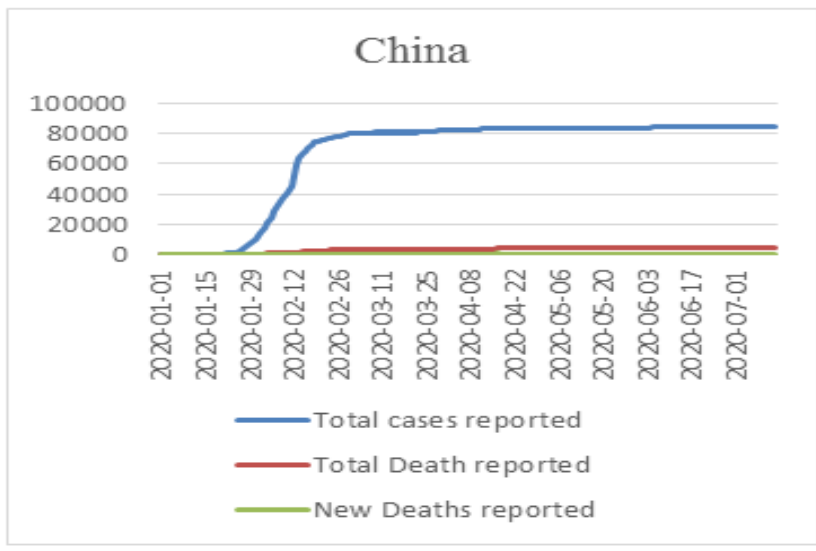

(e)

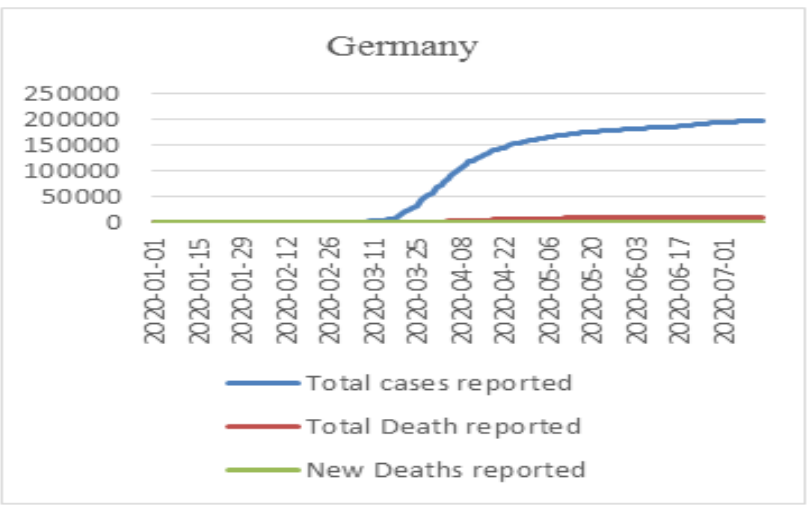

(g)

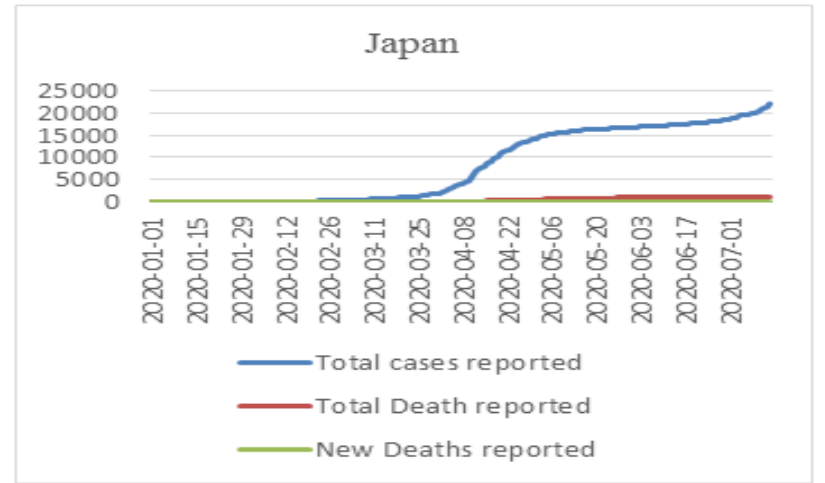

(b)

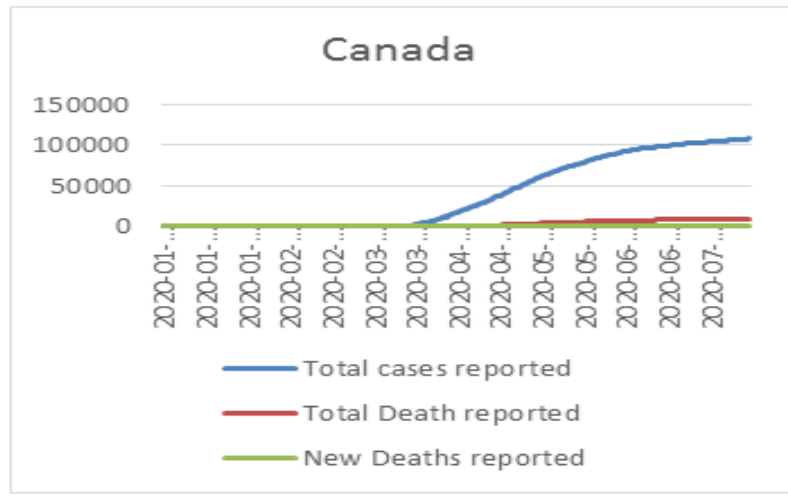

(d)

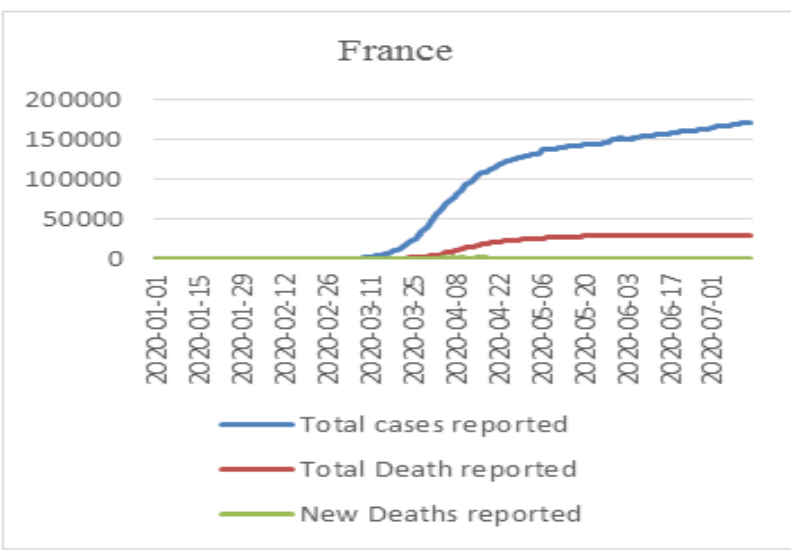

(f)

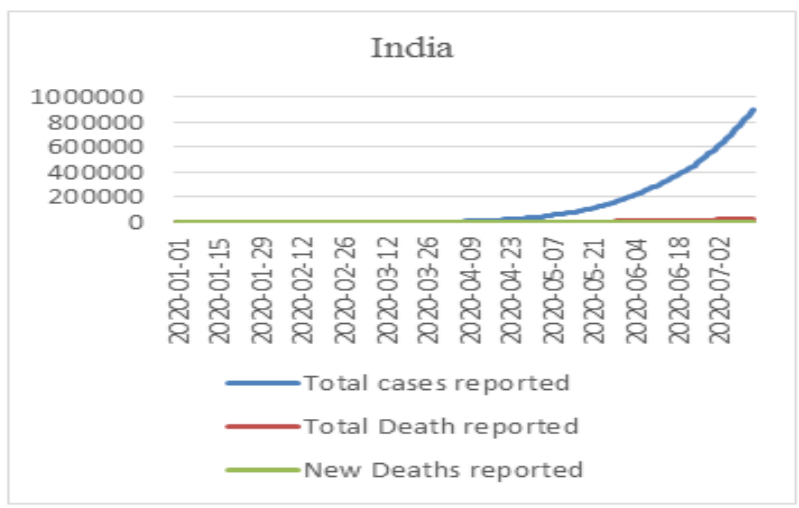

(h)

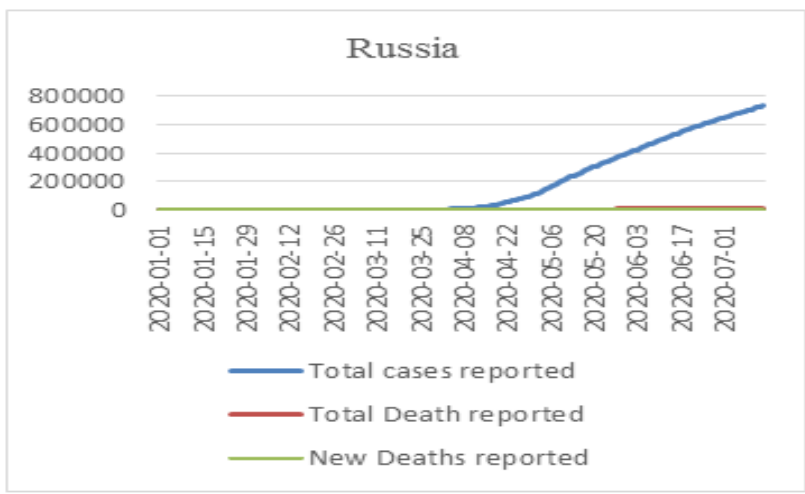


(i)

(j)

UK

400000

300000

200000

100000

0

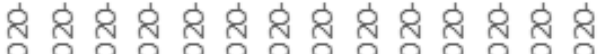

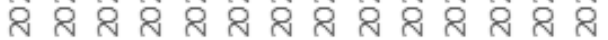

Total cases reported

Total Death reported

New Deaths reported

\section{US}

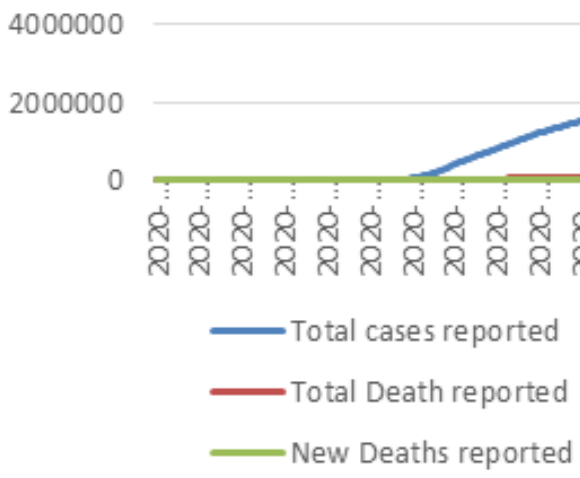

FigureA2. Country-wise total Covid1-19 cases, total deaths, and new deaths reported.

Source: Author's own plotting on data obtained from "ourworldindata"

Note: Figure A2 indicates the number of total Covid-19 infected individuals, total deaths and total new death reported officially daily from 1 st January to 14 th July 2020.

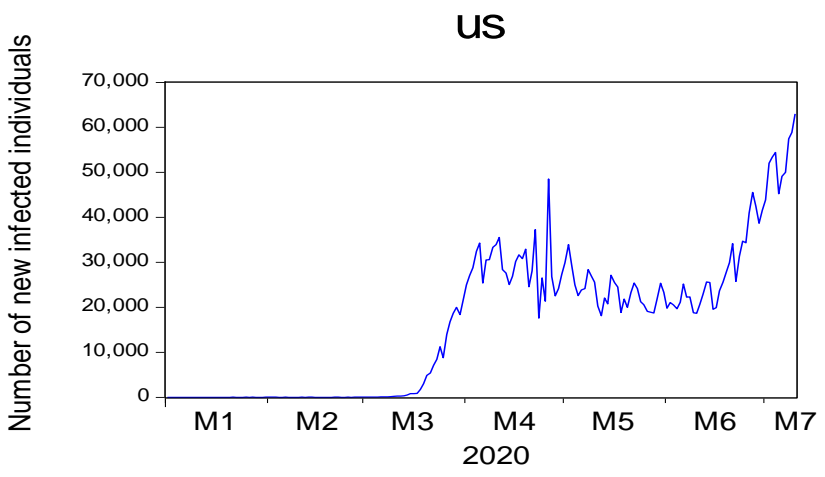

Canada

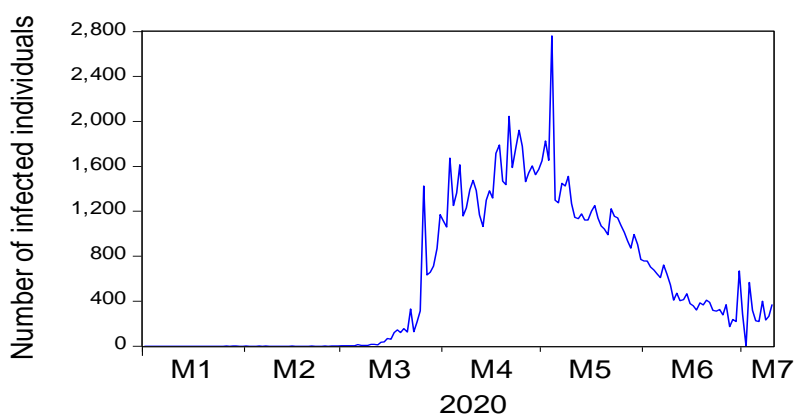

Russia

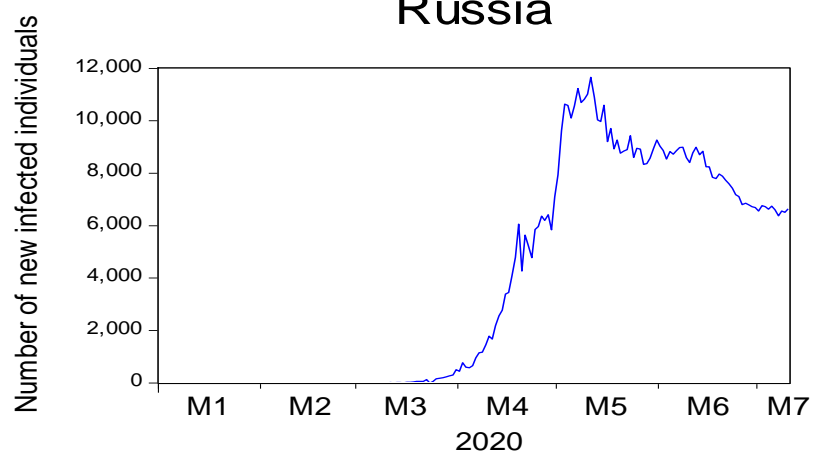

UK

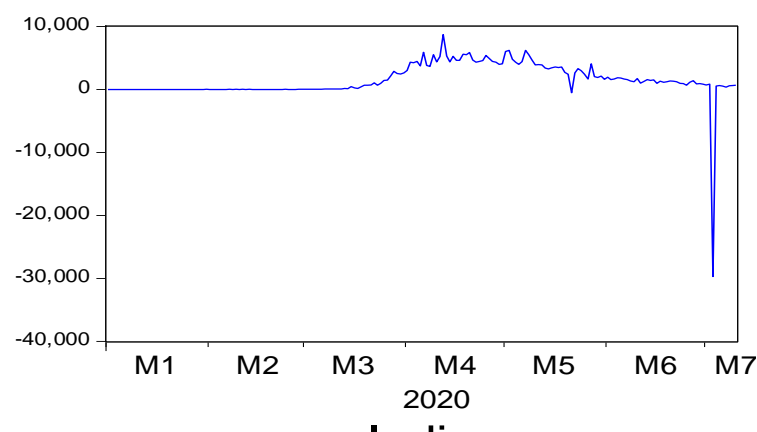

India

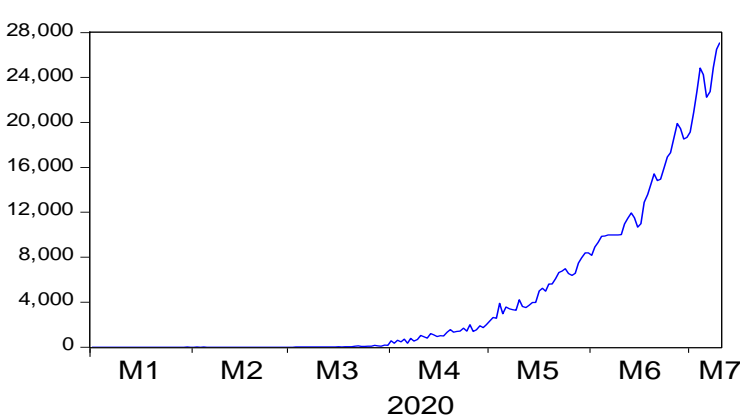

Brazil

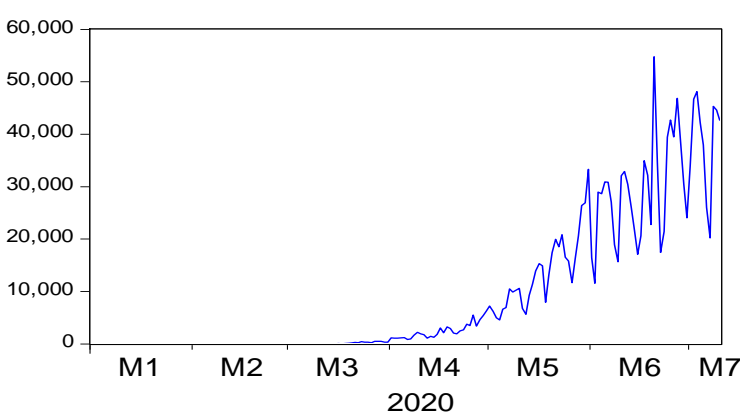



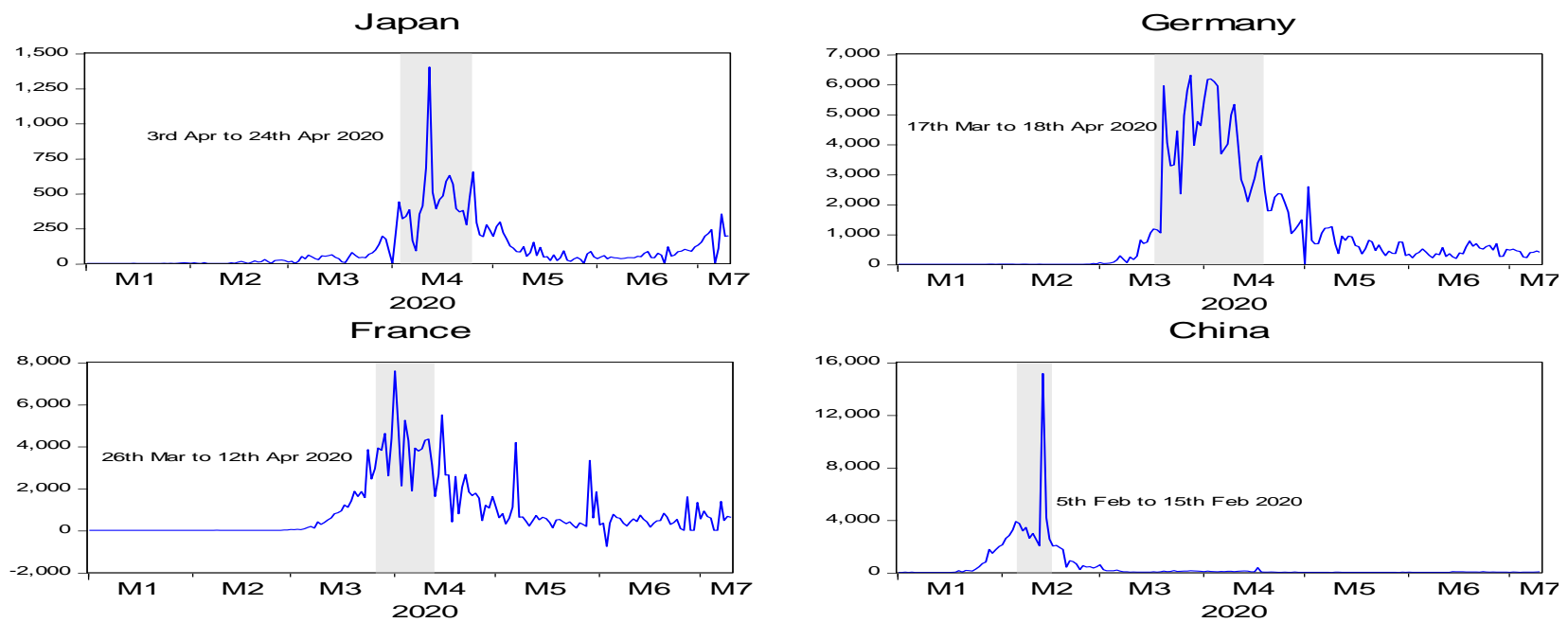

Figure-A3. The trend of number of newly infected individuals.

Source: Author's own estimation, data obtained from 'ourworldindata' ${ }^{12}$. Note; Fig. A2 indicates the number of daily new infected individuals in Covid-19 virus from $1^{\text {st }}$ January to $14^{\text {th }}$ July 2020 and the shaded area indicates the maximum number of infected individuals reported.

Views and opinions expressed in this article are the views and opinions of the author(s), Asian Development Policy Review shall not be responsible or answerable for any loss, damage or liability etc. caused in relation to/arising out of the use of the content.

12 'https://ourworldindata.org/coronavirus' 